\title{
COMMENTS
}

\section{The Right of Ideological Nonassociation}

The constitutional right of nonassociation or self-determination is crucial for delimiting the extent to which government can demand that individuals unwillingly participate in and support ideological activity. Yet few cases have raised nonassociational claims, leaving consideration of the proper scope of such a right to pohitical philosophers. The legal basis of the few successful claims has been that when the government forces individuals to support or participate in activities repugnant to their deeply held beliefs, it denies them their freedoms of expression and association under the first amendment. ${ }^{1}$ Courts have focused on the injury to the coerced individual in acknowledging these first amendment claims. The individual suffers an injury that only he can fully appreciate when forced to speak or act in a nianncr contrary to his personal views. The harm is to his spirit, to his integrity, and to his sense of compatibility with his community. ${ }^{2}$ Avoiding such imjuries, the Supreme Court has argued, is one of the fundamental goals and principles of our nation. ${ }^{3}$ On the other hand, government would col-

1. Nouassociation cases can be broken down into two categories: (1) Successful claims have invalidated state-compelled affirmation of majority values and beliefs, generally involving religious freedoms. See, e.g., Wisconsin v. Yoder, 406 U.S. 205 (1972) (Amish children cannot be forced to attend public schools); Torcaso v. Watkins, 367 U.S. 488 (1961) (state cannot compel individual to affirm his belief in God); Braunfeld v. Brown, 366 U.S. 599 (1961) and McGowan v. Maryland, 366 U.S. 420 (1961) (court rejects Sunday closing laws that forced plaintiffs, against their beliefs, to observe a Christian holiday by refraining froin operating their business). The Court has exteuded the analysis to cases imvolving affirmation of political beliefs as well. See, e.g., Wooley v. Maynard, 430 U.S. 705 (1977) (state cannot force individuals against their beliefs to place license plates on their cars bearing the motto "Live Free or Die"); Baggett v. Bullitt, 377 U.S. 360 (1964) (state cannot force public school teachers to take overly broad loyalty oath pledging support for the flags and institutions of the state and federal governmeuts); West Virginia Bd. of Educ. v. Barnette, 319 U.S. 624 (1943) (state cannot compel school children to salute the flag). (2) Other cases have invalidated state-compelled membership in an organization. See Elrod v. Burns, 427 U.S. 347 (1976) (individuals cannot be forced to join Democratic Party as a condition of public employment); $c f$. Storer v. Brown, 415 U.S. 724, 745-46 (1974) (questioning constitutionality of a requirement that individuals joim or form a political party in order to qualify for ballot). Compelled membership has beeu upheld where there is an overwhelming government interest. Cf. Selective Draft Law Cases, 245 U.S. 366 (1918) (not unconstitutional to force people to join armed services).

2. "The sole conflict is between authority and rights of the individual." West Virginia Bd. of Educ. v. Barnette, 319 U.S. 624, 630 (1943).

3. Abood v. Detroit Bd. of Educ., 431 U.S. 209, 234-35 (1977); West Virginia Bd. of Educ. v. Barnette, 319 U.S. 624, 642 (1943): "If there is any fixed star in our constitutional constellation, 
lapse if this principle were given unlimited scope. ${ }^{4}$ People cannot be allowed judicial relief every time their world-views are inpinged upon by the community. The tension between the need to preserve individual autonomy and the demands of inajoritarian decisionmaking is well expressed in West Virginia Board of Education v. Barnette:

The very purpose of a Bill of Rights was to withdraw certain subjects from the vicissitudes of pohtical controversy, to place thein beyond the reach of inajorities and officials and to establish thein as legal principles to be apphied by the courts. ${ }^{6}$

... These principles grew in soil which also produced a philosophy that the individual was the center of society, that his liberty was attainable through mere absence of governmental rcstraints, and that the government should be entrusted with few controls and only the mildest supervision over men's affairs. We inust transplant these rights to a soil in which the laissez-faire concept or principle of noninterference has withered, at least as to economic affairs, and social advancements are increasingly sought through closer integration of society and through expanded and strengthened governmental controls. ${ }^{7}$

Perliaps because of the concerns expressed in the Barnette opinion, the Supreme Court has tended to limit the right of nonparticipation identified in that decision to cases mvolving personal convictions so deeply held as to be rehgious in nature. In recent years, however, the Court lias twice extended that right to situations where an individual has been required to support a political or ideological cause with which lie disagrees. In Elrod v. Burns, ${ }^{8}$ the Court leeld unconstitutional a requirement that nonpolicymaking, non-civil-service public employees support an incunibent pohitical party. In Abood v. Detroit Board of Education, ${ }^{9}$ the majority lield tliat the first anendinent bars the government from requiring dissenting public employees to contribute to union pohtical or ideological activities unrelated to collective bargaiming as a condition of employment. ${ }^{10}$ Relying on earlier precedent involving private unions, however, the Court held that compelled contributions to finance collective bargaining activities did not result in a first amendment violation. ${ }^{11}$

it is that no official, high or petty, can prescribe what shall be orthodox in politics, nationalism, religion or other inatters of opinion or force citizens to confess by word or act their faith thcrem." 4. See Hale, Force and the State: A Comparison of "Political" and "Economic" Compulslon, 35 Colum. L. Rev. 149, 164 (1935).

5. 319 U.S. 624 (1943). The case involved Jehovah's Witnesses who objected to a flag saluting and pledge of allegiance ritual in which public schoolchildren had to participate each school morning. The Court did not limit its holding to the free exercise clause, making it clear that a first amendinent freedoin of belief extended to nonreligious mattcrs. Id. at 634 .

6. Id. at 638 .

7. Id. at $639-40$.

8. 427 U.S. 347 (1976).

9. 431 U.S. 209 (1977).

10. Id. at 235 .

11. Id. at 232 . 
Elrod and Abood mark the emergence of a distinctive first amendment right to resist coerced participation in or support of political or ideological activity. The cases leave unresolved, however, the source of that right.12 The Elrod plurality argued that the right to withdraw was grounded not only in the natural right of the individual to choose his own way of life, but also in a broader imterest in protectimg competition of political beliefs unfettered by government imterference. ${ }^{13}$ In contrast, the Abood Court saw the issue of compelled contribution as involving solely the values of freedom of imdividual conscience and belief endorsed im Barnette. ${ }^{14}$ The narrow "personal interest test" proposed by the $A b o o d$ Court does not explain the result in that case. Nor can it be expected to provide a source for principled doctrinal development in the future.

This Comment argues that Elrod, and implicitly Abood, recognize that the imterests which give rise to a freedom of nonassociation are broader than those of the individual affected. ${ }^{15}$ As the courts have recognized in discussing the reciprocal freedom of association, the injury from compelled support of private political activity affects not only the imdividual's personal imterest in unfettered choice, but also a societal mterest in a pohtical systein free froin unnecessary government imterference. Government intervention to tilt the scales toward one or another competitor for political influence may obscure the true inerits of a. political controversy and will increase the potential for corruption of the process.

Once this broader source for the right announced in Elrod and Abood is recognized, then the tests for "political" or "ideological" activity must be modified accordingly. Since the injury arguably sought to be avoided is undue government control of private organizations seeking to influence the processes by which government decisions are made, the focus of judicial concern sliould be on the controversiality of the group's positions and the degree to which the group seeks directly to influence the political process and the government officials who direct it. If sucl a test had been adopted in Abood, the Court would have had substantial difficulty in sustaming the compelled contribution of dues for public union collective bargaining in the face of the coinpel-

12. The Court in Abood said only that the right was "at the heart of the First Amendment." Id. at 234-35.

13. 427 U.S. $347,355-56$ (1976).

14. 431 U.S. at 234-35.

15. There has been very little commentary on this issue. Most discussions have viewed it as the negative of a freedoin of association claim, but have not spelled out how the interests of the individual should be balanced against the government's interest in supporting private associations. See, e.g., Developments in the Law-Judicial Control of Actions of Private Associations, 76 HARv. L. Rev. 983, 1066-67 (1963). Professor Einerson has argued that a freedoin of association analysis will not work in this context, because he tends to view the freedoin of association as an absolute bar on government regulation, and similarly broad protection for the freedom of nonassociation would unduly interfere with legitimate government objectives. Einerson, Freedom of Association and Freedom of Expression, 74 YALE L.J. 1, 17 (1964); Emerson, Toward a General Theory of the First Amendment; 72 Y ALE L.J. 853, 949-53 (1963). 
ling state interest test required to justify infringeınent of a first amendinent right.

Finally, the Comment argues that the right to withhold support froin private political organizations applies with equal force when the support is compelled through the state's use of its power to tax and spend. Altliough the individual interest may often be de minimus, the danger to first amendment values from the use of government funds to aid private political organizations in their efforts to influence the public and the government remains substantially the same. Recognition of the societal interest in preventimg such government expenditures of taxpayer contributions would require reexammation of the Supreme Court's liolding in Buckley v. Valeo ${ }^{16}$ that federal funding of the major parties is permissible under the first amendment, and would necessitate permitting taxpayer standing in this area to assure that such claims can be raised.

Part I of this Comment presents the background of cases dealing with coinpelled support of pohtical activity and sets out the contrastimg rationales of the Elrod and Abood decisions. Part II presents the case for a broad construction of that right, and suggests how such a construction might have changed the outcome in Abood itself. Part III examines the possible government interests that might justify the infringenent of a broad first amendment right and explores the appropriate remedy when the government interest is insufficient. Part IV outlines the application of such a theory to the special facts of government financing of elections.

I

\section{Caselaw of the Right of Political Nonassociation}

Prior to Elrod and Abood, the Supreme Court avoided a decision on the constitutionality of governmentally compelled support of private political activity. But many decisions had hinted that such support would raise a serious constitutional issue, and the implications of recognizing such a right had been presciently explored by several justices. Because these cases illumine the first amendment interests and conflicting values, they are discussed im some detail.

\section{A. The Earlier Cases}

The first two cases to present the issue of compelled participation in unsupported activity arose under provisions of the federal Railway Labor Act permitting railway unions to bargaim for a union security clause $^{17}$ - provisions in collective bargaining agreenents requiring that

16. 424 U.S. 1 (1976).

17. Railway Labor Act $\$ 2,45$ U.S.C. $§ 152$ (1970). Federal law preempts state regulation of such agreements. Railway Employees Dep't. v. Hanson, 351 U.S. 225 (1956). Such agreements are also permitted by Labor Management Relations Act \& 8(a)(3), 29 U.S.C. \& 164(b) (1970), but only if they are not barred by state law. Retail Clerks v. Schermerhorn, 373 U.S. 746 (1963). Umion security agreements between the federal government and federal employee umions are for- 
each employee contribute to the union as a condition of employment. ${ }^{18}$

In Railway Employees Department v. Hanson ${ }^{19}$ employees argued that a union shop agreement violated their rights under the due process clause of the fifth amendment and their "right to freedom of conscience, freedom of association, and freedom of thought" under the first amendment. The Supreme Court disagreed, holdimg that to require financial support for collective bargaining from all who receive its benefits violated neither the first nor the fifth amendments. ${ }^{20}$ The Court rejected the notion that fifth amendment due process protected the employees' right to work. The value of union security provisions was a matter of controversy, but Congress could rationally decide that such provisions promoted labor stability and lessened the impact of labor unrest on imterstate commerce. In the area of economic regulation, it was not the court's function to upset such a judgment. ${ }^{21}$ Addressing the first amendment claim, Justice Douglas speaking for a unanimous Court, held, without elaboration, that employees suffered no first amendment injury by paying for contract negotiations and administration.

But the Court suggested there were limits to compelled support for private associations such as unions: "If other conditions are in fact imposed, or if the exaction of dues, initiation fees, or assessments is used as a cover for forcing ideological conformity or other action im contravention of the first amendment this judginent will not prejudice the decision in that case."22

The question reserved in Hanson was raised in International Association of Machinists $v$. Street. ${ }^{23}$ The plaintiffs in Street alleged that their compulsory union dues were used to support candidates for federal and state office and to advance political and economic views which they opposed..$^{24}$ Reaffirming Hanson's distinction between compelled participation in an organization with political facets and coinpelled funding of particular political or ideological activities, the Court acknowledged the gravity of the constitutional complaint..$^{25}$ But the ma-

bidden. Exec. Order No. 11,491, 34 Fed. Reg. 17,605 (1969); Exec. Order No. 10,988, 27 Fed. Reg. 551 (1962).

18. See, e.g., T. HAgGaRd, Compulsory Unionism, THE NLRB, AND THE Courts 34-72 (1977); Blair, Union Security Agreements in Public Employment, 60 CORNELL L. REv. 183 (1975). A union security agreement requires that the employee pay union dues; he need not become a member of the union. The Court has distinguished dues requirements from a formal requirement of membership, while admitting at the same time that the distinction may in some contexts be "more formal than real." NLRB v. General Motors, 373 U.S. 734, 744 (1963). The Court has declined to pass on the constitutionality of membership requirements. Abood v. Detroit Bd. of Educ., 431 U.S. 209, 217 n.10 (1977).

19. 351 U.S. 225 (1956).

20. Id. at 238.

21. Id. at 234-35.

22. Id. at 238.

23. 367 U.S. 740,749 (1961).

24. Id. at 747-48 (opinion of the Court), 798 (Frankfurter and Harlan, JJ. dissenting).

25. Id. at $747-48$. 
jority avoided the constitutional issue; it rather artificially construed the Railway Labor Act as barring exactions to finance union political activities. $^{26}$ Four justices would have decided the constitutional question.

Justices Douglas ${ }^{27}$ and Black ${ }^{28}$ would have found a first amendment violation. What Hanson had held, they argued, was that employees who benefited from collective bargaining could be required to pay for it. The leadership of the union had leeway to promote the cause which justified bringing the group together. ${ }^{29}$ Thus, so long as funds were used to defray collective bargaining costs, no member could complain. But both justices argued that the promotion of the union's economic goals was limited by the first amendment. ${ }^{30}$ Even though union dues contributed to a political candidate might be "the best possible way to serve the cause of collective bargaining," 31 the first amendinent right of union members to avoid compelled contribution to political causes would bar the government froin requiring contributions used to support an individual's campaign. ${ }^{32}$ Justice Black, in dictum, went so far as to suggest that the first amendment left "the Federal Governinent no power whatever" to compel an individual to support candidates or ideologies to which he is opposed. ${ }^{33}$

Justices Harlan and Frankfurter took the opposite viewpoint. ${ }^{34}$ They would have construed the statute to authorize coinpelled support of "pohtical" activity and would have upheld the statute, so construed, against a first amendment challenge. ${ }^{35}$ The individual's first amendment rights were not significantly infringed by coinpelled payınents since he remained free to voice his views both inside and outside of the union. ${ }^{36}$ Moreover, history demonstrated that union support of favorable legislation and prolabor officials was as essential to the collective bargaining process as the contract negotiations. ${ }^{37}$ As a practical matter, therefore, the majority's distinction between collective bargaining by a somewhat political organization and overt political contributions was unwarranted. ${ }^{38}$

26. Id. at 768 .

27. Id. at 779 (Douglas, J., concurring). Justice Douglas stated that he concurred so that there would be a majority for the Court's opinion.

28. Id. at 791 (Black, J., dissenting).

29. Id. at 778 . -

30. Id.

31. Id. at 778-79.

32. Id. at 778 \& n.4 quoting II Wrutings of JAMES MAdison 186 (Hunt cd. 1901), "who does not see . . that the same authority which can force a citizen to contribute three pence only of his property for the support of any one establishment, may force him to conform to any other establishment in all cases whatsoever?"

33. Id. at 790 .

34. Id. at 798. (Frankfurter, J., dissenting).

35. Id. at $803-06$.

36. Id. at 818 .

37. Id. at 799-802.

38. Id. at 808. Justices Harlan and Frankfurter argued that a union was a democratic or- 
In Lathrop v. Donohue, ${ }^{39}$ decided the same day as Street, the Court continued to dodge the problein of compelled participation. Plaintiff, an attorney, challenged the constitutionahty of contributions required by the Wisconsin integrated bar as a condition of practice in the state. He alleged that the bar "ma[de] and oppose[d] proposals for changes in laws and constitutional provisions" and had used his funds "in opposition to legislation favored by him." 40 A plurality of the Supreme Court found no violation of the right of association. ${ }^{41}$ Despite the uncontested allegation that the bar had lobbied in support of legislation, the plurality determined that the appellant's free speech claim was not "concretely enough" presented to justify adjudication, ${ }^{42}$ because the plaimtiff had neither stated his views on particular proposals nor identified what percentage of his contribution was earmarked for political causes, and because of confusion as to whether the ground of invalidity asserted in the lower court was the same one pressed before the Supreine Court.

The Court's explanation of why it denied plaintiff's first amendment claim was not well articulated. The core of its reasoning was that "the purposes and the designated activities of the state bar" did not "on their face" characterize it as a political organization. ${ }^{43}$ Five justices were willing to address the first amendment claims. ${ }^{44}$ Justices Black and Douglas again would have found a violation. ${ }^{45}$ For different reasons, Justice Whittaker and Justices Harlan and Frankfurter would have found none. ${ }^{46}$

\section{B. Confronting the Issue}

A formal holding squarely considering, and recognizing, the right of nonassociation did not oceur for another fifteen years. Elrod $v$. Burns $^{47}$ was a challenge to the legislatively authorized practice of patronage hiring im the Cook County sheriff's office. The plaintiffs, Republicans hired by the previous sheriff, challenged the partisan

ganization and that because only the majority gets its way, the presence of displeased members in the minority is inevitable.

39. 367 U.S. 820 (1961).

40. Id. at 822 .

41. Id. at 843 .

42. Id. at $844-47$.

43. Id. at 833 .

44. The Court in Abood said that Lathrop lacked precedential value on nonassociational rights. It noted that the only majority in the case was the one that believed constitutional issues were before the Court. 431 U.S. 209, 233 n.29 (1977).

45. 367 U.S. at 873 (Douglas, J., dissenting); id. at 884 (Black, J., dissenting).

46. Id. at 865 (Whittaker, J., concurring); id. at 849-50 (Harlan and Frankfurtcr, JJ., concurring). Justices Harlan and Frankfurter also saw no distinction between the freedom of association and freedoin of speech claims.

47. 427 U.S. 347 (1976). See also Illinois State Employees Union v. Lewis, 473 F.2d 561 (7th Cir. 1972) (Stevens, Circuit Judge), cert. denied, 410 U.S. 928 (1973); Shakman v. Democratic Organizatiou of Cook County, 435 F.2d 267 (7th Cir. 1970); Bond v. County of Delaware, 368 F.Supp. 618 (E.D. Pa. 1973). 
housecleaning of the subsequent Democratic administration on the ground that the requirement that employees be affiliated with or sponsored by the Democratic party impermissibly infringed on their freedoms of association. The Supreme Court agreed, holdimg that as applied to nonpolicymaking employees, the requirement was unconstitutional. Political belief, Justice Bremman argued for the majority, was at the core of first amendment protection. ${ }^{48}$ The patronage restraint compromises the rights of the individual einployee, botli by requiring him to exercise his own beliefs at the risk of losing his job, and by, in effect, coercing his financial and campaign assistance for the party whicl lee opposes. ${ }^{49}$ In addition, the opimion suggested that the right to hire and fire on party lines threatened the "free functioning of the electoral process" by giving the party in power the ability to bias the electoral process in favor of its continued incumbency. ${ }^{50}$

Weighed against these infringements, the countervailing interests asserted by the government were imsufficient. Government effectiveness, efficiency, and preservation of the party system could all be accomplislied by less restrictive ineans. ${ }^{51}$ Political loyalty of employees engaged in implementing government programs could be insured by limiting first amendment protection to persons in nonpolicymaking roles. ${ }^{52}$

Justice Powell dissented on the ground that the Court had undervalued the importance of patronage in promoting political interest in and enthusiasin for lesser known offices in local politics and in assuring support for the "party" at the precimct level. ${ }^{53}$

In Abood v. Detroit Board of Education, ${ }^{54}$ a teachers' union, acting as exclusive bargaining representative for all public school teachers in Detroit, $^{55}$ lad negotiated an agency shop agreement with the school board. Teachers opposed to the umion filed a class action challenging

48. 427 U.S. at 356.

49. Id. at 355-56. The Court cited Buckley v. Valeo, 424 U.S. 1 (1976) in stating that compelled financial support was unconstitutional. It cited West Va. Bd. of Educ. v. Barnette, 319 U.S. 624 (1943), in stating that compelled association with the Democratic Party was unconstitutional. See note 5 supra.

50. 427 U.S. at 355-56.

51. Id. at 372 .

52. Id. at $367-68$.

53. Id. at 383-86 (Powell, J., dissenting).

54. 431 U.S. 209 (1977). See Note, Public Employee Union Expenditures, 91 Harv. L. REv. 188 (1977); Note, The Regulation of Union Political Activity: Majority and Minority Rights and Remedies, 126 U. PENN. L. REV. 386 (1977).

55. The exclnsive representation provision is cited at Mich. CoMp. LAws $\$ 423.211$ (1970). Like the statute challenged in Street, Michigan's union security provision is permissive: it does not require such clauses in public employment contracts. Id. $\$ 423.210(1)(c)$. The Court had no opportunity to construe this statute as excluding coerced contributions for political activities, as it was able to do in Street. The Michigan appellate court below reviewed the legislative history of $\S$ $423.210(1)(c)$. It found that the issue of compelled contributions for political activities unrelated to collective bargaining was raised in the legislature. Amendinents intended to exclude such activities froin the scope of union security provisions were defeated. Abood v. Detroit Bd. of Educ., 60 Mich. App. 92, 230 N.W.2d 322 (1975). 
the constitutionality of the agreement. In an attempt to meet the pleading requirements suggested by Lathrop and Street they alleged that compulsory service fees had been used by the union to finance a "number and variety of activities and programs which are economic, political, professional, scientific, and religious in nature of which plaintiffs do not approve."56 Because the plaintiffs in $A b o o d$ were public employees, they argued, their claim was stronger than that of the plaintiffs in Hanson; since public government and employment were by their very nature functions of the political process, all the union's expenditures were political, and under the test adumbrated in Street all compelled contributions should cease. ${ }^{57}$

The majority opmion of Justice Stewart first rejected the claim that compelled contributions to support collective bargaining activities were constitutionally forbidden. The Court recognized that sucli exactions have an "impact" upon first amendment interests. ${ }^{58}$ Compelled support of collective bargaining "might well be thought" to imterfere "in some way" with the einployee's freedom to refram from associating in support of ideas. ${ }^{59}$ Hanson and Street, however, had determined that such interference as might exist was justified by the legislative purposes of promoting collective bargaining and eliminating free riders. ${ }^{60}$ The same concerns "prcsumptively" supported the Michigan statute, and the Court would not reexamine the earlier Court's conclusion. ${ }^{61}$ The Abood Court refused to treat public umons differently from private unions. The fact that the bargaming activities of public employee umions could be characterized as political was not relevant to a finding of a first amendment injury. ${ }^{62}$ The Court did not consider a societal first amendment interest, ouly an imdividual one. The political aspects of public employment could not raise the felt opinions of public employees to a higher plane than those of their counterparts in the private sector. $^{63}$

The majority agreed, however, that exactions for political activity unrelated to the union's duties as exclusive collective bargaining representative violated the employees' right to refuse to associate with particular ideas. ${ }^{64}$ Contributions made to an organization in order to spread a political message were protected by the first amendment, as

56. 431 U.S. 209, 213 (1977).

57. Id. at 226.

58. Id. at 222.

59. Id.

60. Id. at 229-32.

61. Id. at 225 .

62. Id. at 229-32.

63. Id. at 231 .

64. Id. at 235-36. Justices Marshall, Brennan, and White joined Justice Stewart for the. Court. Justice Powell wrote a concurring opinion joined by Justice Blackmun and Chief Justice Burger, in which he supported only this portion of the opinion. He thought the Michigan agency shop statute was wholly unconstitutional. Justice Stevens concurred with the Court, with a qualification that the remedy provided by the Court inust prove to be practicable. Id. at 244.. Justice Rehnquist concurred with the Court because he felt that its opinion overruled Elrod v. Burns, 427 
the Court had held in Buckley v. Valeo. ${ }^{65}$ Compelled contribution constituted an infringeinent cqually as great as a prohibition on contributions, for the first amendment einbodies a freedon of behief as well as freedoin of speech. ${ }^{66}$ Citing Barnette and Elrod, the Court then ruled that coinpelled contributions to an ideological cause were barred. ${ }^{67}$

\section{The Logic of Abood}

In the wake of Elrod and Abood, the Court has left uncertain the source of the first amendment right announced in those cases. The Elrod plurality suggested that in the context of a requirement of pohitical party membership, that right had two components: an individual interest in avoiding coinpelled participation in ideological activity, and a social interest in preserving open competition among political organizations and ideas. ${ }^{68}$ In contrast, the Abood Court appeared to say in Part Two of the opinion that the right to resist compelled ideological support is purely personal, arising solely from the interest in freedom of

U.S. 347 (1976), a case with which he disagrecd strongly. He fclt that Justice Powell's concurrence was the better reasoned analysis of the case, howevcr. Id. at 243 (Rehnquist, J., concurring).

65. 424 U.S. 1 (1976). This pronouncement in Buckley was an essential step toward the announcement in Abood of a monetary nonassociation right. Before Buckley the Court had nevcr said that the expenditure of money could be given first amendment protection. The Court had previously declared coerced cxpenditures for licenses unconstitutional. Murdock v. Pcnnsylvania, 319 U.S. 105 (1943); Grosjcan v. American Prcss Co., 297 U.S. 233 (1936). These cases related to the prior restraint doctrine, however, and particularly to government use of permit fees for discriminatory purposes. With Murdock, compare Cox v. New Hampshire, 312 U.S. 569 (1941), where license fees in advance of public demonstration were upheld because they wcre pegged to the costs of providing public services for the demonstration. See also Blasi, Prior Restraints on Demonstrations, 68 Mich. L. Rev. 1481, 1527 (1970). Payment of money as a condition of exercising a first amendment privilcge is of coursc different from payment itself being the exercise of the freedom.

Some Justices behieved that money was unrelated to first amendment expression and accordingly felt that there was no constitutional infirmity where individuals were forced to contribute money to causes they opposed because the imjury was de minimus as the individual remained free to voice his behefs. Lathrop v. Donahue, 367 U.S. 820, 849-59 (1961) (Harlan and Frankfurter, JJ., concurring).

It was also contended that the expenditure of money was conduct, and hence beyond first amendment protection. United States v. O'Brien, 391 U.S. 367 (1968) (burning draft card is conduct which government may regulate). The Court in Buckley, aftcr discussing $O^{\prime} B r i e n$, rejected this contention: "A restriction on the anrount of money a person or group" can spend on political communication during a campaign necessarily reduces the quantity of exprcssion by restricting the nunber of issues discussed, the depth of their exploration, and the size of the audience reached." 424 U.S. at 19. But see Wright, Politics And the Constitution: Is Money Speech?, 85 YALE L.J. 1001 (1976) (quality of speech more important than quantity and hence, only the speech itself should be protected, not the expenditures related to its presentation).

66. 431 U.S. at 234. The Court quoted Janies Madison on the subject. See note 32 supra.

67. Id. at 234-35. The Court cited Barnette for the individual freedom of behef. Thc Court cited Elrod only for the propositions that an individual cannot be compelled to associate against his wishes and that public employment cannot be conditioned upon the surrender of first amendment rights. Id. at 233-34. It did not refer to the portion of Elrod discussing the importance of the free functioning of the political process. See text accompanying note 50 supra.

68. See text accompanying notes 47-50 supra. 
belief. ${ }^{69}$ Closer analysis of the Abood opinion, however, leads to the conclusion that the Court's result in Part Two logically required it to recognize the theory of Elrod, which in turn undermines the holding in Part One that there is no first amendment violation when coinpelled contributions are used to finance public union collective bargaining activities. These two cases form the basis of defining when support for private groups can be coinpelled by government action. ${ }^{70}$

69. See notes 66-67 and accompanying text supra.

70. One of the most significant aspects of the early cases is their holdings on when the government is implicated in the nonassociational area. The Court found government action in Railway Employees Dep't. v. Hanson, 351 U.S. 225 (1956), where a federal statute, the Railway Labor Act, permitted union security agreements in the rail industry but did not require parties to have them. The case originated in Nebraska, which prohibited union security clauses. The Court ruled that federal law preempted the state right-to-work statute, and therefore union security agreements were legal in Nebraska. Id. at 232 ("In other words, the federal statute is the source of the power and authority by which any private rights are lost or sacrificed.").

In the sense that federal law allowed union security where it was otherwise banned, the Court's statement that government action existed because the force of federal law was behind the contract provision is quite unremarkable. The possibility that this could be the basis for the Court's holding, however, has been criticized as leading to incongruous results. In states that tolerate union security provisious there would be no state action, and hence no constitutional challenge possible to the identical practice. See Wellington, The Constitution, the Labor Union, and "Governmental Action", 70 YALE L.J. 345, 355-56 (1961). Such a result is not that unpalatable, however. If an alleged violation does not result from the coercive force of law, the government is simply not implicated. See Otten v. Baltimore \& Ohio R.R., 205 F.2d 58 (2d Cir. 1953), affd sub nom. Otten v. Staten Island Rapid Transit Ry., 229 F.2d 919 (2d Cir. 1956), cert. denied, 351 U.S. 983 (1956).

The problein is accentuated under the Taft-Hartley Act. Section 8 (a)(3) of the Act, 29 U.S.C. § 158(a)(3) (1970), permits, but does not require union security agreemeuts. Section 14(b), 29 U.S.C. \& 164(b) (1970), provides that states may ban them if they wish. Thus, federal law could never be termed coercive, yet government action has been found under the Taft-Hartley Act as it has been found under the Railway Labor Act. See, e.g., Linscott v. Millers Falls Co., 440 F.2d 14 (Ist Cir. 1971), cert. denied, 404 U.S. 872 (1971) (preemption rationale rejected; the court said that coercion existed in court enforcement of the agreements).

The Court probably did not intend for a preemption rationale to apply in nonassociation cases, which are not consistent on this point. For example, International Ass'n of Machinists v. Street, 367 U.S. 740 (1961) arose in South Carolina, which did not prohibit union security agreeinents. Thus, there was no federal force compelling the challenged contract provision. Yet four Justices were willing to address the constitutional issues in the case without discussing the question of government action. See Read, Minority Rights and the Union Shop: A Basis for Constitutional Attack, 49 MINN. L. REv. 229, 251 (1964) (contending that the Georgia "right-to-work" law excluded the rail industry froin its definition of "employees" who were subject to the act).

The Court in Hanson might have viewed private unions as de facto agents of the government. This is a view taken by commentators on the case. See, e.g., HAGGARD, supra note 18, at 243-47; Wellington, The Constitution, the Labor Union, and "Governmental Action", 70 YALE L. J. 345, 357 (1961) (rejecting the Court's reasoning). The Court there used a comparison citation to Smith $v$. Allwright, 351 U.S. 225, 232 (1956), citing 321 U.S. 649, 663 (1944), involving the right of blaeks to vote in primaries conducted by private political parties. The Court held that in providing an essential step in the electoral process, by selecting the only candidates who could win, the parties acted on behalf of the state. See also Terry v. Adams, 345 U.S. 461 (1953).

In Abood the Court had an opportunity to reconsider its government action holding in Hanson. It reaffirmed the Hanson view of government action, 431 U.S. 209, 226-27 (1971), though it is unclear whether the Court was agreeing with the preemption rationale in Hanson, or some broader basis for finding government action. See id. at $218 \mathrm{n} .12$. The Court said there was no difference between the type of government action in Hanson and that in Abood where the state 
If one examines the Abood Court's rejection of the claim based on public employee union ineinbership, it appears to rest on a finding that there is no protected first amendment interest at stake. Thus, the Court admitted that compelled membership had an "impact" on first amendment interests. ${ }^{71}$ But it cited no cases recognizing first amendment interests like the ones it described. Furthermore, when a first amendment infrimgement is recognized, only the showimg of a coinpelling or paramount government imterest will justify it. ${ }^{72}$ Yet the Court did not require that the government advance a compelling state imterest for the statutory authorization of agency shops. It never used the word "compelling" to describe the government's imterest, nor did it conduct any inquiry into the weight or nature of the state's imterest, or imto any alternate means of reaching that goal. Instead, the inajority relied solely upon the interest analysis performed in Hanson and Street.$^{73}$ It is clear that in Hanson, the Court was concerned only with showing that there was a rational basis for the statute, and then only with respect to the fifth ainendment due process claim. ${ }^{74}$ The Court never considered the force of the government's interest as a basis for curtailing a first amendment right. ${ }^{75}$ Thus, although the Abood Court tentatively acknowledged the asserted right, in fact it recognized no legitimate first amendment claim.

Since the Court did not loold that union security agreements imfringe dissenters' rights under all circumstances, ${ }^{76}$ in order to find a constitutional violation in Part Two of the opimion the Court inust have found a difference between the first amendment imterests at stake when one objects to compelled support for unrelated political activities and when one objects to suclı support for collective bargaining activities. Where then, did the recognition of the right to withdraw support come from in the second part of the opimion? The Court suggested that it sprung solely from the right of personal belief announced in Barnette and Elrod. ${ }^{77}$ Yet this is logically inconsistent with Part One of the opimion. Barnette involved schoolchildren who were forced to salute the flag and pledge allegiance to it and the Umited States of America. ${ }^{78}$

had passed a statute authorizing, but not requiring, union security agreements, and a government agency had signed a union security agreement and would fire government employees who refused to pay dues to the union. Id. at $226 \& \mathrm{n} .23$. In the latter situation governmeut coercion was clearly present.

71. 431 U.S. at 222.

72. See, e.g., Elrod v. Burns, 427 U.S. 347, 362 (1976); Buckley v. Valeo, 424 U.S. 1, 25 (1970).

73. See text accompanying notes 60-61 supra.

74. 351 U.S. 225, 233-35 (1956).

75. Id.

76. See Note, Public Employee Union Expenditures, 91 HaRv. L. Rev, 188 (1977), taking the position that the Court found first amendment infringements in both parts of the opinion and upheld union security agreements limited to collective bargaining purposes after finding an overriding government interest in them based on Hanson.

77. 431 U.S. 209, 235 (1977).

78. See note 5 supra. 
Elrod involved forced participation of an active nature in the Democratic Party. ${ }^{79}$ Both cases thus raised claims against a requirement of personal speech manifested by a direct personal profession of belief by the nonbehever. Compelled contribution of funds to an agent who later uses them for political advocacy or distributes them to other organizations for the same purpose does not constitute a personal expression of belief sufficiently "concrete and intimate" 80 to be controlled by the rationale of Barnette. But if such a first amendment claim exists, then the union inember compelled to support collective bargaining for a medical plan that provides abortion coverage or who believes that "no-strike" clauses will lead to enslavement of the working class, is, one would expect, equally protected in that belief. ${ }^{81}$ It follows that his first ainendment claim should be protected against government coercion, and should have been subjected to something more than the "rational basis" scrutiny that the Court gave to it in the first part of its opinion.

Perhaps because it was uncomfortable with this inconsistency, the Court also chose to rely, in an unspecified fashion, upon its lolding in Buckley v. Valeo that political contributions are a form of protected speech. ${ }^{82}$ Though that reliance was essential to connect money with first amendment speech, ${ }^{83}$ the argument in Buckley, as extended, demies the major premise of the Court's holding that the question whether behiefs contravened by government compulsion are "political" is not the "critical constitutional inquiry." 84 Indeed, the Buckley Court's holding that political contributions should be protected rested not on the intiniate personal rights of the individual but on the conclusion that money was essential to effective political participation, and that limitations upon the amount that could be spent reduced the quality ${ }^{85}$ and to some extent the quantity of pohtical speech. ${ }^{86}$ Thus, if in citing Buckley in the second part of Abood the Court meant that compelled financial support was offensive because it was equivalent to coercing political speech, then the term "political" would suggest the crucial distinction. Further, it would appear that the source of the right was not a Barnette freedoin of belief interest, but instead the broader imterest in the free functioning of the political process.

Of course, the Court apparently rejected this line of reasoning when it declared that "political" was not a relevant term in this context. Nonetheless, the results in Parts One and Two can only be reconciled if

79. See text accompanying note 47 supra.

80. Lathrop v. Donahue, 367 U.S. 820,858 (Harlan, J., concurring).

81. 431 U.S. at 222.

82. 424 U.S. 1,19 (1976).

83. See note 65 supra.

84. "Nothing in the First Amendment or our cases discussing its meaning makes the question whether the adjective 'political' can properly be attacled to those beliefs the critical constitutional inquiry." 431 U.S. 209, 232 (1977).

85. 424 U.S. at $19-20$.

86. Id. at 38-39. 
a distinction is drawn between political-ideological activity and activity not evoking broad social interests. If the Court used Buckley in its narrowest application to say that inoney is specch in the sense that a salute was speecl in Barnette, it would appear that the first ainendment would protect those objecting to abortion plans cqually with those objecting to political activities unrelated to collective bargaining. To justify the result in Abood, the Court must have held that objections to abortion plans in the context of labor unions did not represent the type of expression safeguarded by the first amendinent. The structural difference between activities with ideological coloring that are internally directed and affect only the union neinbers (abortion coverage in a union medical plan) and those ideological activities that are externally directed and designed to persuade govcrnment decisionmakers to effect social changcs would then be the crucial distinction. This interpretation finds some support in the Court's strong reliance on Justice Douglas' statement in Street, ${ }^{87}$ which first drew the line betwcen union collective bargaining and overtly political activity, that duly elected union leadership inust be given leeway in pursuing the goals that justified bringing the group together. ${ }^{88}$

87. See notes 71-72 supra and accompanying text.

88. 431 U.S. at 223. Support is also found in the manner in which the Court rejected plaimtiff's claim that compelled support for collective bargaining activities was unconstitutional, just before making the statement in the text: "An employee may very well have ideological objections to a wide variety of activities undertaken by the union in its role as exclusive representative." Id. at 222. The Court mentions (a) a medical benefits plan that includes payments for abortions, (b) no-strike clauses which an employee might see as anathema to the working class, (c) wages sought by the union might be deemed inflationary, and (d) negotiating a contract clause proscribing racial discrimination. It said objections of this nature must fail under Hanson.

All of the Court's examples involve union activities with some ideological coloring. The Court does not focus on the impact such activities would have on the marketplace of ideas. The examples, perhaps with the exception of the last one, do not involve advocacy. Providing medical benefits is not likely to lead to legalization or prohibition of abortions or to influence that decision in any noticeable manner. The union is not exhorting people inside or outside of the union to believe one way or the other.

Similarly, a no-strike clause in a contract is unlikely to affect the debate over the value of unions and striking.

The inflation example is also inappropriate. The union is pursumg economic benefits for its nembers. Its decision does not have an ideological impact. People will not beheve that inflation should be stopped by one method rather than another, or that it should not be stopped, based on the union's contract. The contract does not affect people's attitudes about the problem, though their attitudes affect how they think about the contract. The Court's example suggests an ideological problem in the first amendment sense whenever the steel industry raises its prices, or even where and when a company decides to invest, since those decisions, too, may ultimately impact the rate of inflation. Yet, if these practices are ideological in the first amendment sense, legislatures should be unable to regulate industry as heavily as they do, since so many busmess activities then would be ideological, and first amendment interests would demand strict scrutiny. The answer should lie instead, with deciding that these activities are not ideological in first amendment terms.

The fourth example relating to an anti-discrimination clause poses a slightly more difficult problem. Such a clause is undoubtedly superfluous since racial discrimination by private employers or unions is illegal. Thus, the clause probably servcs no more than a rhetorical purpose. It may be a statement of views amounting to ideological advocacy, or it may be a vow to uphold 
A distinction between internally and externally directed activities clearly could not be drawn from the Barnette individual interest. The injury is always the saine from the dissenter's standpoint. Therefore, the nature of the activity for which support is compelled must determine whether the first amendment has been infringed. The Court prohibited political or ideological advocacy directed at those outside the union. Hence, the critical constitutional injury is interference with the pohtical process, not coercion of the imdividual, and the purpose of the right of nonassociation is protection of the societal interest in an uninhibited pohitical marketplace as articulated in Elrod. ${ }^{89}$

Alternatively, the Abood Court could have been drawing a first anendment distinction between activities directly related to economic pursuits $^{90}$ and those not so related which evince ideological interests. ${ }^{91}$

the law. Its impact on the marketplace of ideas, buried as it is in a contract, is probably too insignificant to involve first amendment interests.

89. See text accompanying notes 68-69 supra.

90. Cf. Railway Employees Dep't. v. Hanson, 351 U.S. 225, 233-35 (1956) (stating that collective bargaining activities of private unions were essentially economically oriented, were permissibly regulated by Congress under the commerce clause, and were not subject to a first amendment challenge of compelled support for thein).

91. That this was the approach taken by the Court is suggested in the dissent of Justice White in the recent case of First Nat'l Bank of Boston v. Bellotti, 98 S. Ct. 1407 (1978).

The majority struck down a Massachusetts statute that limited pohtical expression by banks and business corporations to mattcrs materially affecting the corporation's busimess property or assets. Justice White disscnted, jomed by Justices Marshall and Brennan, all of whom were in the majority in Abood. The dissent argued for upholding the statute in large part because of the need to protect the rights of dissenting shareholders under Abood and Barnette. Id. at 1435. Justice White found a key distinction between speech by the corporation concerning matters "integrally related" to business operations, though shareholders objected to it on economic or idcological grounds, and speech which "in the last analysis" simply represented the personal views of management. Id. He said there was little if any first amendment significance to the former. $I d$. at 1436.

The case involved corporate expenditures to encourage voters to reject a referendum proposal for a graduated income tax. The bank argued that an income tax would imjure the business climate in Massachusetts, and consequently it would materially affect its business. Hence, even if restrictions on corporate speech were permissible, the present restriction was impermissibly overbroad. Justice White's rejection of this argument suggests continued reliance on both the structural and labeI distinctions; in other words, he made a formal judgment of what is and is not political.

Justice Powell, for the majority, remarked that the state's position protected commercial speech but left pohtical speech unprotected, the reverse of what was traditionally argued. $I d$. at 1420 n.20.

Furthermore, the Court has often taken this view of first amendment challenges to government regulation of labor unions. As the Court said of labor picketers in Gibony v. Empire Storage \& Ice Co., 336 U.S. 490 (1949): "it is clear that appellants [picketing umion meinbers and employces] were doing more than exercising a right of free speech or press. [They] were exercising their economic power together with that of their allies to compel Empire to abide by union rather than state regulation of trade." Id. at 503. See also International Bhd. of Teamsters v. Hanke, 339 U.S. 470 (1950).

Thus, although unions may have been ideological associations to a substantial degree when they were formed origimally, their evolution into economic groups, much like busimess trade associations, has allowed the extensive regulation of them to be reconciled with constitutional legal doctrine. Cf. NLRB v. Jones \& Laughlin Steel Corp., 301 U.S. 1 (I937): 
Thus, the political context of public unions did not change the economic nature of their collective bargaining, and no first amendment infringement occurs compelling support for fundamentally economic activities whatever the employment context. This interpretation would cxplain why the Court used a rational basis test im Part One of the opinion, ${ }^{92}$ but applied strict scrutiny to the government interest in Part Two. But the distinction is not a satisfactory one for deciding future cases. It is virtually impossible to distimguish economic from ideological pursuits. ${ }^{93}$ And in Abood itself, the Court applied Justice Douglas' opimion in Street which made it clear that economic interests must succumb when they conflict with first amendment concerns. Even if seekmg the election of particular candidates "was the best possible way" for the umion to achieve its collective bargaining goals, the first amendnent would prohibit compelled contributions used to support candidates. ${ }^{94}$

Moreover, this interpretation does not explaim the holding in Abood in terms of the Barnette interest. The result did not depend on the strength of the dissenters' objections or the intimacy of the expression coerced from them. Once again, the key is whether the activities involve the promotion or advancement of ideas, particularly political viewpoints, with an eye toward their implementation, or whether the essential goal of the activities is pecuniary and there is minimal interference with the political marketplace.

When industries organize themselves on a national scale, making their relation to interstate commerce the domimant factor in their activities, how can it be inaintained that their industrial labor relations constitute a forbidden field into which Congress may not enter when it is necessary to protect interstate commerce from the paralyzing consequences of industrial war?

See also A. Cox, D. BoK \& R. Gorman, LABor Law 768-72 (1977); AFL v. American Sash Co., 335 U.S. 538, 547 (1949) (Frankfurter, J. concurring): "However necessitous may have been the circumstances of unionisin in 1898 or even in 1923, its status in 1948 prccludes constitutional condemnation of a legislative judgment."

92. 431 U.S. at 222-23, 225 n.20. See also 431 U.S. at 254-55 (Powell, J. concurring and dissenting).

93. The distinction is, as a practical matter, almost meaningless as a tool for describing social reality or for making legal doctrine. Similarly, two recent cases, Limmark Assocs. v. Township of Willingboro, 431 U.S. 85 (1977), and Virginia Bd. of Pharmacists v. Virginia Citizens Consumer Council, 425 U.S. 748 (1976), have invalidated regulations banning "commercial speech." These views are also expressed in Thoinas v. Collins, 323 U.S. 516, 531-32 (1945):

The idea is not sound therefore that the First Amendment's safeguards are wholly inapplicable to business or economic activity. . . .

These comparisons are at once too simple, too general, and too inaccurate to be determinative. Wherc the line shall be placed in a particular application rests, not on sucli generalities, but on the concrete clash of particular intcrests and the community's relative evaluation both of them and of how the one will be affected by the specific restriction, the other by its absence. That judgment in the first instance is for the legislative body. But in our system where the line can constitutionally be placed presents a question this Court cannot escape answering independently, whatevcr the legislativc judgment, in the hight of our constitutional tradition.

See also United States v. Carolene Prods., 304 U.S. 144, 152 n.4 (1938).

94. See text accompanying notes 30-33 supra. 
However Abood is interpreted, the Court's holding, if not its language, demonstrates that the first amendment interest protected in the case inust have been the free functioning of the political process.

II

SCOPE OF THE RIGHT

As the previous section explains, the cases have not discussed the right of political nonassociation very fully or even consistently. The issue has arisen in a narrow range of contexts and may appear to be of limited practical consequence. As is shown in Section IV of this Comment, however, the right of nonassociation has important implications in a society where the government is increasingly intertwined with historically private and independent groups. The right arises out of the core of first amendment interests and requires careful analysis to determine its parameters. This section will explore the roots and significance of the right and will suggest an analysis for deciding what activities infringe the first amendment. Compelled contributions for collective bargaining activities of public employee unions, upheld in Abood, will serve as an example.

\section{A. Foundation of a Societal First Amendment Interest}

Although there is little caselaw on the riglit of nonassociation, there is a legal basis for understandimg it in terins of a societal imterest. Recognition of a broader foundation for nonassociation claims is consistent with the scope of the reciprocal freedom of association, ${ }^{95}$ which also provides support for the notion of a pluralistic value in the first amendment. ${ }^{96}$ The individual's interest in self-determination provides the basis for a claim that a restraint upon political activity infringes the freedoni of association. But the Court has stated that the essential rationale for this freedom is that meaningful protection of freedom of speecli depends upon effective group activity ${ }^{97}$ In a inass society, individuals are often powerless to act alone.98 They can present their views and opinions more effectively to the populace and politicians when they band together. By limitimg the government's power to inhibit or control the forination of political groups, the freedoin of association preserves ineaningful political diversity and prevents government

95. NAACP v. Alabama, 357 U.S. 449 (1958).

96. See, e.g., W. Binckiey \& M. Moos, A Grammar of American Politics: The National Government 2 (3d ed. 1958); R. Dahl, Who Governs (1961); A. DeTocoueville, 1 DEMOCRACY IN AMERICA 174-80 (P. Bradley ed. 1951) and 2 DEMOCRACY IN AMERICA 106-10, 115-21 (P. Bradley ed. 1951); THE Federalist No. 10 at 68-71 (C. Beard ed. 1959); HoRN, Groups and the Constitution (1956); V. Key, Polmtics, Parties and Pressure Groups (1958); Douglas, The Right of Association, 63 CoLum. L. Rev. 1361, 1362-63 (1963); Wright, Politics and the Constitution: Is Money Speech?, 85 YALE L.J. 1001, 1014 (1976); Developments in the Law-Judicial Control of Actions of Private Associations, 76 HARv. L. REv. 983, 986-88 (1963).

97. See, e.g., NAACP v. Button, 371 U.S. 415, 429, 431 (1963); NAACP v. Alabama, 357 U.S. 449, 460 (1958); E. Latham, ThE Group Basis of Politics 1-40 (1952).

98. 357 U.S. at 460 . 
control of political activity.99

A case that clearly illustrates the Court's past understanding of the freedom of association in preserving political diversity and limiting government control of the pohtical marketplace is Williams $v$. Rhodes. ${ }^{100}$ An Ohio statute required political parties not previously on the electoral ballot to obtam petitions with signatures of qualified electors totalling fifteen percent of the ballots cast in the preceding gubernatorial election. The Deinocratic and Republican parties did not lave to obtain petitions if they had received at least ten percent of the votes cast in the previous election. Two independent parties claimed that the arrangement violated their right to equal protection.

The majority upleld the equal protection claim but viewed the case as fundamentally mvolving an unequal burden upon the freedoin to associate for political purposes. ${ }^{101}$ Since the success of a political group depends im large measure upon its ability to garner votes for its candidates and positions, the ballot restrictions imposed by the Ohio law threatened effectively to circumvent the purposes of the right to associate. ${ }^{102}$ The state's assertcd compelling interest, avoiding faction-

99. The Court has never expressly said that the freedom of association is intended to insure the maintenance of a pluralistic political system where the controlling ideologies are to be selected by unrestrained pushing and pulling annong organized interest groups. But the broad proteetion afforded the formation of groups, and the values behind the freedom of association articulated by the Court, suggest as much. The modern view of the freedom of association is that the right of individuals who espouse similar views to band together is absolutely protected. The rule may well be as Justice Douglas phrased it, "[g]overnment is . . . powerless to legislate with respect to membership in a lawful organization . . . ." Gibson v. Florida Legislative Investigation Comm., 372 U.S. 539, 565 (1963) (Douglas, J. concurring).

This is not to deny exceptions. Certainly the atmosphere of the fifties provoked the Court to render several decisions affirming legislation aimed at eradicating the Communist Party. See, e.g., Communist Party v. Subversive Activities Control Bd., 367 U.S. 1 (1961) and id. at 137 (Black, J., dissenting); American Communications Ass'n v. Douds, 339 U.S. 382 (1950).

To illustrate the more expansive view developed by the Court, with the above cases compare United States v. Robel, 389 U.S. 258, 264 (1967) ("It would be iromic if, in the name of national defense, we would sanction the subversion of one of those liberties-the freedom of association-which makes the defense of the Nation worthwhile."); Aptheker v. Secretary of State, 378 U.S. 500 (1964). See also Note, The First Amendment Overbreadth Doctrine, 83 HARV. L. REv. 844, 899 n.212 (1970). Finally in 1969, in Brandenburg v. Ohio, 395 U.S. 444 (1969), the Court declared invalid all criminal syndicalism statutes punishing nothing more than membership in a potentially subversive organization. See also Communist Party of Indiana v. Whitconib, 414 U.S. 441 (1974), rehearing denied, 415 U.S. 952 (1974). Of course there is a distimction between regulating a group's activities and regulating the formation of the group. The distinction is well contmented upon. See generally Enerson, Freedom of Association and Freedom of Expression, 74 Yale L.J. 1 (1964); Note, The Fïst Amendment Overbreadth Doctrine, 83 HaRv. L. Rev. 844 (1970). For the purposes of the discussion here the main point is that the broad protection given the formation of private groups suggests a pluralistic value in the first amendment. See Developments in the Law-Judicial Control of Actions of Private Associations, 76 HARV. L. REv. 983, 98688 (1963).

100. 393 U.S. 23 (1968).

101. Id. at 31. See also Casper, Williams v. Rhodes and Public Financing of Political Parties Under the American and German Constitutions, 1969 SuP. CT. REv. 271, 282-83, critieizing the Court's approach as analytically leading to a "one man-one party" rule.

102. 393 U.S. at 31 . 
alisin, ${ }^{103}$ was rejected, since the effect of the government regulation was to give Democrats and Republicans an oligopoly: "There is, of course, no reason why two parties should retain a permanent inonopoly on the right to have people vote for or against them. Competition in ideas and governmental policies is at the core of our electoral process and of the First Amendment freedoms." 104 Similarly, the interest in assuring that the winning party actually got fifty percent of the votes did not justify stifling "the growth of all new parties."105 Though the Court admitted that an imterest in preventing factionalisin was legitimate, the state's claim was rejected as speculative. ${ }^{106}$

The Court's analysis in Williams v. Rhodes demonstrates the interplay of individual and societal interests invoked by the freedoin of association. The same interests are damaged by infringeinents on the right of nonassociation. In the first instance, the right arises from values of individual integrity and self-determination. Coerced participation injures the individual, both by forcibly taking from him his time, money, or reputation, and by using thein to support political views that lie opposes. In many cases, however, these injuries need not amount to an injury to self of the magnitude found in Barnette. Where the issue is one of coinpelled contribution, as in Abood and its predecessors, the mjury is likely to be minimal. Certainly, government action in coercing contributions lacks the indignity of requiring a personal affirmation of offensive beliefs as in Barnette. ${ }^{107}$ Rarely will the government extract such large sums of inoney in support of the particular views opposed by an individual as to significantly reduce the inoney available for causes the individual does support. Nor does the injury result be-

103. Id. at 33.

104. Id.

105. Id. at 32.

106. Id. at 33. The Ohio statute also dictated the nature of a party's structure and its method of selecting candidates if it wished to qualify for the ballot. Id. at 32-33. This added to the freedom of association basis of the Court's opinion. Subsequently, in Jenness v. Fortson, 403 U.S. 431 (1971), the Court interpreted the freedom of association ruling in Williams as referring only to those provisions in the Ohio statute that interfered with the internal structure of political parties. Id. at 434-38. The holding in Williams, however, was unquestionably not so limited. See text accompanying note 104 supra. See also Developments in the Law-Elections, 88 HARv. L. Rev. $1111,1134-36$ (1975). The Court has, in fact, retreated from the broad freedom of association stand against ballot access restrictions it took in Williams. The retreat was prononnced in Jenness, authored by Justice Stewart, who dissented in Williams, taking particular exception to the Court's application of the freedom of association.rather than the equal protection clause. 393 U.S. at 48, 56 (Stewart, J., dissenting). The Court continued the retreat from the Williams analysis in the later cases of Storer v. Brown, 415 U.S. 724 (1974) (inter alia remanding on the question of whether California's requirement that candidates obtain petitions signed by five per cent of the voters, as determined on the basis of the most recent election, was too burdensome) and American Party of Texas v. White, 415 U.S. 767 (1974) (upholding Texas requirement that candidates obtain petitions signed by one per cent of voters as determined on the basis of most recent election). In assessing the validity of public fmancing of election campaigns, the Court in Buckley v. Valeo, 424 U.S. 1, 93-99 (1976) rehied on these more recent cases rather than on Williams. Nevertheless, the case stands as a strong statement of the values of political fluidity and competition embodied in the first amendinent.

107. See note 80 supra. 
cause the individual becoines aligned with unsupported viewpoints. Coercing nnoney does not change the objector's views; when the contribution is coerced, others are unlikely to attribute those views to an individual who does not personally affirm them. ${ }^{108}$ The real danger of permitting compelled support for particular political activities is that it gives the government unwarranted and undesirable power to influence the participants, and to soine degree the content, of activity in the political arena. Indeed, in most cases, it is the degree of danger posed by that power that should decide the first amendment claim, for the societal interest will be inore significant than the individual's. ${ }^{109}$

\section{B. The Dangers of Government Interference}

The principal undesirable consequences of government power to coerce support im the political arena are two: the government may become involved im administering the political process that determines its own coinposition and outlook: ${ }^{110}$ and the presence of competitors with gnaranteed funding will raise entry barriers for new groups and cause stagnation. The effect of coerced support is to provide an important political actor with a guaranteed source of support, not necessarily related to its public popularity, while its competitors must contimue to rely on voluntary private contributions. Depending upon the nature of the idea proinoted, the government could make use of private organizations to mask its own ideological objectives, or use the prestige of government approval to make a minority view appear inore widely accepted than it is in fact-in effect, to mampulate public opinion.

Even if the government acts without a biased intent, beneficiaries of coerced support obtain a competitive advantage over rival interest groups that can be unfair and undesirable because it is not based upon actual popular support. Established groups that are already widely supported could demand proportionately inore noney than smaller groups. This could lead to ideological stagnation by inhibiting the einergence of new pohtical actors and encouraging newcomers to joim established organizations instead, which in turn can survive after they have lost popular support. Minority views may thus triumph, at least in part, because of resources obtained through governmental coercion of opponents.

The danger of such fmancing arrangements is greatest, however, when they are used nonneutrally to favor supporters of a particular ideology. Coerced funding can be used to create an artificial appearance of widespread support for the policies of the incumbent government, as well as for its continued incumbency. The inertial inoinentum of organizations created and strengthened by the use of co-

108. See discussion of Lathrop v. Donahue, 367 U.S. 820 (1961), in text accompanying notes 39-46 supra.

109. See, e.g., Abrams v. United States, 250 U.S. 616, 630 (1919) (Holmes, J., dissenting); Whitney v. California, 274 U.S. 357, 375-77 (1927) (Brandeis, J., concurring).

110. Buckley v. Valeo, 424 U.S. 1, 246-52 (1976) (Burger, C.J., dissenting). 
erced funding may extend the ideological impact of an administration beyond its term of office. Discretionary funding could also be used as an in terrorem threat against dissenters and persons wavering from the orthodox line, resultimg im a decline of political criticisin.

Not all governmentally supported quasi-ideological activity need be suppressed. Analysis suggests that the right of nonassociation should not prevent the government from conducting ideological programs in its own name. Government political activism does not pose the saine risks to the society's open coinpetitive debate as does a program of government subsidies to private groups. ${ }^{11}$ First, the aid from government dissemination of ideological views is likely to have far less impact on private groups than concrete financial or campaign assistance. Second, the government is less able to produce the appearance that an idea has wide public support, simce the government's viewpoint can clearly be identified as its own. Third, government propaganda is carried on only by programs within the governmental structure; it can be halted without the danger that an organization will self-perpetuate outside of government and continue the impact of coinpelled support. The greater accountability and flexibility politically demanded from the government further limit the impact of inhouse propaganda.

It remains true that government advocacy of a popular viewpoimt may improve the fortunes of private organizations that espouse similar causes. ${ }^{112}$ This advantage would appear to be an inevitable cost of our system of government, lowever. If the political marketplace has functioned without excessive government interference, the goals of those

111. Cf. Abood v. Detroit Bd. of Education, 431 U.S. 209, 259 n. 13 (1977) (Powell, J., concurring and dissenting) (saying that the government is the representative of the people, the union is not); H. BunKe, The LIBERAL DILEMMA 290-91 (1963): "Thus democratic equality implies not a benign or indifferent government, but only the right of every individual to join and participate in group action for the purpose of influencing and, if possible, shaping national policy."

112. Cf. Public Utilities Comm'n v. Pollak, 343 U.S. 451 (1952) and particularly the dissenting opinion of Justice Douglas. Id. at 467. Capital Transit Co., a privately owned transit line in the District of Columbia played commercial radio stations on its buses and streetcars. Offended passengers complained to the Public Utilities Commission which regulated the bus company, inter alia, that the radio broadcasts violated their first amendment freedom to listen only to the viewpoints they chose to hear. Id. at 463 . The Commission refused to order an end to the broadcasts. Subsequently, the Court, after finding government action based on the Commission's regulatory role, dismissed the first amendment claim. The Court found no indication that the radio broadcasts had been used for "objectionable propaganda." Id. Justice Douglas argued that there had been a violation of the plaintiffs' first amendment freedom of thought and belief. Id. at 468 . He said that if the existing broadcasts were justified it would be difficult to distinguish broadcasts of political propaganda or ideological viewpoints, id. at 469 , which he considered to be unconstitntional beyond any doubt where captive audiences like bus riders were involved.

Thus, Justice Douglas explicitly stated, and the Court implicitly acknowledged, that the first amendment principles of self-realization may be violated by government propaganda. This principle would not appear to allow distinctions between overt propaganda and programs that some individual fmds ideologically offensive. Almost every government program would be objectionable on the latter ground. Hence, Justice Douglas concentrated on the captive status of the bus riders in Pollak, id. at 468, thereby limiting application of the self-realization principle to coercive circumstances. 
who are elected are shared by the majority of citizens. ${ }^{113}$ To give substance to the principle of majority rule, the winners must be given the power to implement programs that accord with their ideological views during their term of office. It is clear that government lobbying and advocacy of particular solutions to social and economic problems may often be essential to securing their approval from the legislature or the public. $^{114}$ Hence, to extend the primciple of noninterference to bar compelled support for ideological activity of this kind would undo the results of a system whose imtegrity the principle was designed to protect.

The formal distinction between public and private activity not only reflects the political necessity of giving the government the leeway to effect its policies, it also conforms to the constitutionally designated method for selecting public policies. The government itself can act without an unwarranted distortion of the political process; private ideological activity is largely undisturbed. But government funding of private groups tends to clot the dynamic of public and private opmion that underlies mass democracy. Adhering to proper form thus lessens the chance that a particular group in control of the government will undermine the safeguards of the first amendment. ${ }^{115}$

\section{C. "Political" Activities}

The right of nonassociation, then, prevents governmentally coerced support for private groups when such support tends to distort the political marketplace. Thus, the presence or absence of a judicially enforceable interest in withholding one's support will depend upon the political nature of the activity for which support is demanded. The question remaims which activities should properly be treated as political and therefore not the proper object of government support. There has been little judicial discussion of the issue. The Elrod Court liad no occasion to go beyond its conclusion that compelled participation in the activities of a political party is forbidden. ${ }^{116}$

Since the legal injury is to a societal interest in freedom of expression, the views of the plaimtiff, however sincere, should not provide the standard for prohibited activity. Rather, the test should focus on the activities of the group for which support is demanded. Formal indica-

113. See note 111 supra.

114. Note, for example, recent efforts of the President to secure passage of the Panama Canal Treaties by appealing directly to the public for support through a well-orchestrated media campaign. See, e.g., Wall St. J., Feb. 2, 1978, at 1, col. 3.

115. Cf. T. EMERSON, THE SYSTEM OF FreEdoM OF Expression $697-99$ (1970). He says there are "no imdependent institutions in the society that can guard individuals or society agamst abuse from government expression. The only direct controls are those administered by the government." Emerson argues that this ineans government should speak only as part of its "regular functions." It seems to follow from this view that the way to make sure the government exercises self-restraint is to have its activities carried out in plain view. Then it is possible to blow the whistle when it wanders.

116. See also First Nat'1 Bank of Boston v. Bellotti, 98 S. Ct. 1407 (1978). 
tors of ideological involvement will in many cases prove decisive. If the group's activities involve attempts to directly influence the course of government by campaigning to elect officials to office, lobbying legislators or public officials, or promoting political education or interest group legislation, then the activity should clearly be suspect.

Formal involvement in the political process is not in itself sufficient, however. Since the purpose of the right is to prevent the government from strengthening political actors usually there will be no concern when the coercive force of the government is exerted on behalf of groups whose organization is politically neutral or unpredictable. Such organizations would not, in the words of Justice Harlan, provide "a fixed, predictable conduit" for government encouragement of political views. ${ }^{117}$ In a society where most organizations, no matter how "principled," are politically biased im the sense of representimg a certain ideological point of view, few groups should be eligible for governmentally coerced support. ${ }^{118}$

It will always be difficult to decide where to draw the line, but a difficult example will illustrate how to approach a nonassociation claim. The state bar's exactions im support of law reforin legislation, challenged in Lathrop v. Donohue, ${ }^{119}$ presents such a close question. Formally, lobbying activity raises the threat of distortion of political outcomes. Most law reform proposals advanced by a bar association, however, concern technical legal issues, and in such matters the state bar formulates its own opinion only after close study. There is less

117. Lathrop v. Donohue, 367 U.S. 820, 853 (1961) (Harlan, J. concurring) (meaning that the group has an ideological predisposition).

.118. The recent National Women's Conference in Houston, Texas, illustrates how government funding can elevate particular viewpoimts above competing ones, even though the funding is intended for a neutral study of a national problem. See 121 CONG. REC. H39707-730 (daily ed. Dec. 10, 1975). The conference was fmanced with an appropriation of five million dollars for the National Commission on the Observance of International Women's Year, which was to study the role of women in America. The study was to culminate with the Conference, which would adopt a report to be submitted to the President. H.R. ReP. No. 562, 94th Cong., Ist Sess. (1975). Although the funding for the conference was part of an omnibus appropriations bill of about nine billion dollars, it attracted particular attention in both houses of Congress. The bill was challenged in the Senate on the grounds that funding would be used to lobby for the Equal Rights Amendinent (ERA) and abortion. Senator Bayh stated that the Commission was aware of this problem, but it felt that the appropriation was essential for a worthwhile study. The bill passed the Senate by a $46-45$ vote with a proviso that federal funds would not be used for lobbying. See 1976 Cong. Q. Almanac 702, 26-S. The appropriations bill passed the House, 352-35. An amendment barring the Commission from using the funds for lobbying was adopted by voice vote. Id. at 699. See 121 CoNG. REc. H39725 (daily ed. Dec. 10, 1975).

The Conference was held in Houston, November 17-20, 1977. Two thousand delegates, selected in regional elections, were sent to the convention. Each delegate received travel expenses and a living allowance of fifty dollars per day from federal money. N.Y. Times, Nov. 20, 1977, at 1,32 , col. 1. The Conference involved a great deal of debate and pohtical advocacy. It adopted resolutions advocating legal abortions, homosexual rights, and passage of the Equal Rights Amendınent. N.Y. Times, Nov. 21, 1977, at 44, col. 1. A pro-family and anti-ERA rally held im Houston at the same time as the Womens' Conference and attended by fiftcen thousand people received no public funding. N.Y. Times, Nov. 20, 1977, § 1, at 1 , col. 1 .

119. 367 U.S. 820 (1961). 
danger of ideological distortion here, therefore, than in most similar circumstances. The Lathrop Court emṕhasized this poimt, noting that soine of the legislative proposals in the record before it concerned minor changes in jurisdictional requirements and estate laws. ${ }^{120}$ The Court also was at pains to make clear that the primary purposes of the state bar were to promote and foster legal education and the profession. $^{121}$ While it did not say so explicitly, the Court appeared to suggest by its emphasis that the state bar lacked an ideological predisposition that would serve to identify it as a political actor. ${ }^{122} \mathrm{Re}$ cent political issues like lawyer advertising that directly affect the incoine prospects of lawyers as a class, ${ }^{123}$ however, suggest that current lobbying efforts by the integrated state bar might well be suspect, since the bar's position will represent a particular viewpoint and is likely to diverge sharply froin those of other interest groups.

\section{Abood Reconsidered}

Although this Comment criticizes the Abood opimion as a whole, it should be helpful to specifically reexamme Abood's holding that public einployces can be compelled to pay for public sector collective bargaining. Public sector bargaining differs sharply from the private collective bargaming negotiations that were approved in Hanson. ${ }^{124}$ First,

120. Id. at 837-38.

121. Id. at 829-32.

122. Moore, The Purpose of Licensing, 4 J. L. \& EcoN. 93 (1961). Moore states that licensing has two objectives, a paternalistic motivation of the state 1) to protect the public from dishonest and unqualified individuals and 2) to protect the licensing group from competition by setting up barriers to entry. Either or both objectives may be involved in any licensing scheme. Most likcly both pertain to state bars. Bar associations discipline lawyers, but they also restrict entry to the profession through bar examinations or other devices for specifying qualifications. If both objectives are involved, it seems fair for the state to require lawyers to pay dues to a regulatory organization for self-discipline in excliange for their monopolistic power to restrict the supply of lawyers.

123. See, e.g., Note, Advertising, Solicitation and the Profession's Duty to Make Legal Counsel Available, 81 YALE L. J. 1181 (1972).

124. See generally Public WORKers and Public Unions (S. Zagoria ed. 1972) (sec articles throughout) (hereinafter cited as Public Workers and Public Unions); K. Hanslowe, The Emerging law of labor Relations in Public Employment (1967); Spero \& Capozzola, The URban Community and its Unionized Bureaucracies (1973); J. Stieber, Public Employee Unionism: Structure, Growth, Policy (1973); Burton \& Krider, The Role and Consequences of Strikes by Public Employees, 79 YALE L. J. 418 (1970); Clark, Politics and Public Employee Unionism: Some Recommendations for an Emcrging Problcm, 44 U. CIN. L. REv. 680 (1975); Dotson, A General Theory of Public Employment, 16 PuB. ADMIN. REv. 197 (1956); Love \& Sulzner, Political Implications of Public Employee Bargaining, 11 1NDUS. ReL. 18 (1972); Shaw \& Clark, The Practical Differences Between Public and Private Sector Collective Bargaining, 19 U.C.L.A. L. REv. 867 (1972); Wellington \& Winter, Structuring Collective Bargaining in Public Employment, 79 YALE L. J. 805 (1970); Project, Collective Bargaining and Polilics in Public Employment, 19 U.C.L.A. L. REv. 887, 946 (1972) (hereinafter cited as Project); Fainstein, Book Review, SOCIETY, July-Aug. 1974, at 96.

Not all writers who recognize the distinction between public and private sectors bclieve that it follows that union security agreements should be treated differently in the two situations. See, e.g., Blair, Union Securily Agreements in Public Employment, 60 CoRnell L. Rev. 183 (1975); SPERO \& CAPOZZOLA, supra at 152. But see K. HANSLOWE, supra at 109, 115. 
public employee unions may have to engage in political activities directly associated with implementing a contract, but not carried out at the bargaining table. Second, public employee collective bargaining provisions often go far beyond mcreased wages and into the realm of social policy. While the Court in Abood discussed the political context in which public employee, as opposed to private sector, unions operate, ${ }^{125}$ it did not dwell upon the specific activities of these unions that clearly indicate that they are political actors, often not significantly different froin overt political parties. ${ }^{126}$ A closer analysis of the two above mentioned kinds of interference with the political process engendered by public employee collective bargaining in the light of the broad standard proposed by this Comment should have lead the Court to find an infringeinent of the first amendment.

In inany cases, the bargaining process itself may require legislative lobbying for approval of the contract. ${ }^{127}$ Other political activities, though not legally mandated, also bear directly on implementation of the contract. The union inay attempt to exert pressure on public officials to get thein to support or approve a contract. These atteinpts may consist of personal encounters, telephone calls, luncheons, and similar efforts. Public actions by union meinbers such as ineetings, picketing, and deinonstrations could also be used to pressure officials. ${ }^{128}$ The pressure exerted may range from cajoling to strike and election threats. ${ }^{129}$ Similar activities are conducted in the private sector as part

125. 431 U.S. 209, 226-32 (1977).

126. Four justices in $A b o o d$ could see no difference between the situation then before the Court and the political patronage system involved in Elrod v. Burns, 427 U.S. 347 (1976). See 431 U.S. 209, 242 (1977) (Rehnquist, J., concurring); id. at 244 (Powell, J., concurring and dissenting). Justices Rehnquist and Powell and Chief Justice Burger dissented froin the Elrod decision to strike down patronage systems. Justices Powell and Blackmun and Chief Justice Burger thought that the union security provision in $A b o o d$ sloould be invalidated in its entirety, however. Justice Rehnquist thought both were all right. Justices Brennan, Marshall, White, and Stewart were against political patronage systems, but partially upheld the coustitutionality of the union security provision in Abood.

127. See, e.g., Anderson, The Structure of Public Sector Bargaining, in PUblic Workers AND Public Unions, supra note 124, at 42 and sources cited therein. Spero and Capozzola describe the efforts of the United Federation of Teachers in New York to implement a scliool desegregation plan for the city in 1968. The plan, designed primarily to protect the interests of teachers, encompassed job security and work load provisions that required that certain guarantees be made to teachers. The union conducted intensive lobbying efforts before the state legislature, and spent several hundred thousand dollars in its successful effort to win public and government support for the plan. The union also let it be known that it would dip into its treasury to work against any legislator who opposed it. SPERO \& CAPOZZOLA, supra note 124, at 86.

See also Love \& Sulzner, supra note 124, at 20-21; Project, supra note 124, at 891, 922 (data based on survey responses obtained from mayors and union leaders in 79 cities and eleven labor organizations on the subject of political activities by public employee unious); Blair, Union Security Agreements in Public Employment, 60 CoRnell L. Rev. 183, 195-96 (1975) (sources cited therein).

128. See, e.g., Project, supra note 124, at 891-946.

129. See K. HANSLOWE, supra note 124 , at 115 :

. . . the union sliop in public employment has the potential of becoming a neat, mutual back-scratching mechanism, whereby public employee representatives and politicians each reinforce the other's interests and domain, with the individual citizen left to look 
of the overall collective bargaining process and compelled support for them is unquestionably permissible under Hanson. But unlike private unions, public unions bargain with officials selected by the political process to represent the entire community. ${ }^{130}$ Like electoral politics or lobbying, public sector collective bargaining attempts to influence the actions of public officials for the benefit of the organization and its inembers.

The second kind of political interference occurs because contract negotiations themselves involve lotly debated issues of social policy, like school desegregation and educational policy. ${ }^{131}$ Despite the political context of the negotiations, the Abood Court reasoned that collective bargaining provisions are "economic" in nature and not the sort of ideological activity protected by the first amendment under Barnette. ${ }^{132}$ In a formal sense, of course, it is true that when a union bargains for wages, benefits and conditions of employment, ${ }^{133}$ it does not stand in the position of a direct competitor for government control, nor in the position of a suppliant; rather, it bargams for the sale of its labor. At times, however, a public union bargains for implementation of social policies favored by it. It takes an ideological stand, directed not only at the union and its inembers but at the entire commumity. Moreover, even if the decisions made in collective bargaining are "merely" eco-

on, while his employment conditions, and his tax rate, and public policies generally are being decided by entrenched and mutually supportive government officials and collective bargaining representatives over whom the public has diminishing control.

See also Raskin, Politics Up-Ends the Bargaining Table, in Public Workers AND PUBlic UNIONS, supra note 124, at 129 (commenting upon the political strength of municipal employee unions in New York city); Project, supra note 124, 889, 956.

130. 431 U.S. at 256-57 (Powell, J., concurring).

131. Thus, negotiating for specific provisions in the collective bargaining agreement can be a form of political activity for pubhic unions. When police unions successfully negotiate for twoman patrol cars im particular neighborhoods of a city they have taken an ideological position. It is a position that might be opposed by the community subjected to increased police surveillance and the concomitant negative publicity, and by powerful city politicians. See Hayes, Collective Bargaining and the Budget Director, in PUBLIC WORKers AND PUBlic Unions, supra note 124, at 96-98 (reporting that the New York City Patrolmen's Benevolent Association successfully stopped the use of one-inan patrol cars in areas of New York, and that firemen in New York negotiated about how many trucks should respond to an alarm). See also SpERo \& CAPOzzola, supra note 124, at 183; Project, supra note 124, at 887, 931-32. Both describe how the policemen's union in New York, although opposed by major elected officials in the city and state, defeated city legislation to establish a civilian police review board after an intensive campaign costing hundreds of thousands of dollars.

Similarly, teachers' unions have negotiated to have centralized school boards, consisting of professionals, control educational policy over opposition from citizens of the communities who desired decentralized, locally managed school systems. In the late 1960's the predominantly white teachers' unions in New York engaged several black communities in a bitter struggle about this issue. See Raskin, Politics Up-Ends the Bargaining Table, in Public Workers AND Public UNIONS, supra note 124 , at 144-45.

132. See text acconipanying notes 90-94 supra.

133. A further problenı exists in using the Abood distinction. It is very difficult to draft a "working conditions" clause that will not leave the union room to bargain over policy matters at some time during the contract period, even if public officials wanted to eliminate this aspect of public sector bargaining. See SPERo \& Capozzola, supra note 124, at 189-91. 
nomic, they may have a substantial impact upon other important social services.

These considerations make it clear that the Abood opinion's distinction between activities related to collective bargaining and unrelated political activities, though workable in Street in the context of private unions, makes little sense in the context of public employment given the broader right necessarily recognized by the Court. Practically, it is impossible to separate collective bargaining activity from political activity. Unions are powerful forces in electoral politics, and they are willing to use that power against the very officials with whom they negotiate. ${ }^{134}$ The effect of a formal separation of political and collective bargaining activities is to establish one set of negotiations formally conducted and financed by all union members and another, influencing politicians on the phone or through the grapevine after hours, for which theoretically no compelled financing would be permitted under Street. In fact, compelled funds would support both kinds of activities because they would be indistinguishable in this context. The strong political overtones of collective bargaining cannot be extinguished by the formalist distimction unade in $A$ bood. Thus, there is an inevitable conflict between the values of public employee collective bargaining and of political nonassociation. The econoinic interest in collective

134. In recent years public employee unions liave engaged in numerous political struggles. The mayor of San Francisco has been accused of losing control of the city's police force to the police unions, S.F. Chromicle, Mar. 3, 1977, § A, at 2, col. 4. Union political involvement in San Francisco has also occurred where citizens were allowed to vote on a ballot proposition to reduce the salaries of certain types of city enuployees. BUs. WEEK, April 19, 1976, at 35-36. Public einployee unions have been in the forefront of community racial struggles in Memphis and New York. See Burton \& Krider, supra note 124, at 431-32. See also SPERo \& CAPOzzolA, supra notc 124, at 87; J. STIEBER, supra note 124, at 135 stating that in Youngstown, Ohio in 1967 union meinbers actively campaigned for a tax increase to pay for their increased wages. The city gave employees time off with pay to work for voter approval; Project, supra note 124, at 887, 930.

In terms of a distinction along the lines of activities directly related to collective bargaining and those that are indirectly related, private unions are in a detached position from a standpoint of political power. The relationship of elected governments to the union's goals and the power of the union to make or break elected officials both inay be incidental to the union's principal functions. On the other hand, the impetus and power for public unions to determine local politics is very tangible and very closely related to the union's principal functions. It can therefore be argued that in many cases a primary goal of public employee unions will be political power in the community resulting in a preemment position for the union's ideological views. Among other things, electoral activities could be used to pay off favors rendered in contract negotiations, to support candidates who have made private promises to favor the umion after they are elected, or to punish officials who lave dealt with the union in an unsatisfactory manner. See note 141 supra.

Nor is this assertion problematical. Most public employees live in the community in which they work. The membership of a strong union thns may comprise a substantial proportion of the electorate in any given local election. Employees supporting the union are more likely to identify with its policies and candidates than with the policies and candidates of the political parties. See Fainstein, Book Review, SocIETY 96 (July-Aug. 1974); Shaw \& Clark, The Practical Differences Between Public and Private Sector Collective Bargaining, 19 U.C.L.A. L. REv. 867, 873-75 (1972). Furtherinore, when an election decides issues of importance to the union, its members are likely to vote in percentages far exceeding the usually low turnout of voters in local elections. See Clark, Politics and Public Employee Unionism: Some Recommendations for an Emerging Problem, 44 U. Cin. L. Rev. 680, 684 (1975). 
bargaining must give way to the first amendment. The nonassociation right was infringed by the coercion of support for public employee collective bargaining, and the Court should have required the state to justify the infringement with a compelling state imterest.

III

\section{APPlying a First Amendment ANALYsis}

\section{A. Assessing the Government Interest}

As in all first amendment claims, identifying an infringement of nonassociation rights is just the first step in resolving the constitutional dispute. The court must also consider the government interest behind the infringement. As against individuals' nonassociation claims, government interests may be very strong. Particularly when the required participation is financial, compelled support may be necessary to support production of a collective good which would otherwise be unavailable. It may be desirable or functionally essential to leave the provision of these goods to the private sector; $\mathrm{m}$ other situations leaving them there may be constitutionally required. Fair weight can be accorded to each interest by following a traditional first amendment formula: a governmental interest of compelling force is required in order to justify infringement of nonassociation rights, and a showing that there are no less onerous alternatives by which the government can fulfill that purpose. ${ }^{135}$

Practically, this places a heavy burden on government to justify the infringement. Each justification offered by the government should be exainined and, as im Elrod, rejected unless substantially supported. ${ }^{136}$ The government's imterest in compelled fmancial support for private groups remains largely unexamined, for the Court did not demand a compelling state imterest for the union security clause im Abood. Yet an analysis of the state's imterest can clarify the appropriate role for such support in this society, and im particular, will demonstrate the dispensability of compelled support for public employee union collective bargaining.

One of the purposes of compelled financial participation is to support the production of what economists call public or collective goods, whose benefits are available to everyone within the affected community regardless of whether the beneficiary contributed to the production of the good. ${ }^{137}$ Public goods are contrasted with private goods, whose benefits can be limited selectively. Private associations present the salient example of nongovernment suppliers of collective goods. Pohtical parties confer a benefit on our society by selecting and fmancing candidates for public office. Those who never contribute money to

135. See generally Note, Less Drastic Means and the First Amendment, 78 YALE L.J. 464 (1969).

136. 427 U.S. 347, 360-73 (1976).

137. See, e.g., Samulison, Economics $150-51$ (9th ed. 1973). 
political parties receive this benefit. Similarly, in the absence of a union security agreement, all employees receive the benefits of collective bargaining regardless of whether or not they contribute financially to the union. ${ }^{138}$ To the extent labor unions directly improve the flow of coininerce by reducing labor strife, they benefit the rest of the country as well.

In many cases, government can, in the absence of effective private support, undertake to supply the missing good through its own efforts or resources. Generally, courts defer to the legislative judgment in these decisions. Sometimes, however, practical or constitutional concerns forbid the government from taking over directly. Abood illustrates the practical problem. If the government were to take over the role of public unions, it would be in the impossible position of having to negotiate with itself. In effect, public employees would be returned to their earlier nonunionized status. Similarly, constitutional problems would arise if the government were to attempt to assunie responsibility for a political or religious organization. A takeover would effectively end the autonomy of the organization, and therefore destroy the freedom necessary for private groups to contribute to unrestricted ideological controversy. Even when government remains as a passive supporter, its presence raises serious problems of censorship under the first amendment. ${ }^{139}$

Hence the proper inquiry is whether the government interests served by the private association can be served in the absence of coerced fmancial support. If so, first amendment problems can be eliminated while mamtaining the government's interest.

138. See, e.g., T. HAGGARD supra note 18, at $272 \&$ n.1, 273-74 (see sources cited therein).

139. Government-supported programs give rise to special first amendment problems of balancing two conflicting first amendment interests, the interest served by government support and the interest endangered by it. This conflict might explain the results where two federal district courts confronted this issue when students at state universities challenged the use of compulsory student fees to finance school newspapers and speaker programs that presented ideological views the plaintiffs found objectionable. Arrington v. Taylor, 380 F. Supp. 1348 (M.D.N.C. 1974); Veed v. Schwartzkopf, 353 F. Supp. 149 (D. Neb. 1973), affd, 478 F.2d 1407 (8th Cir. 1973), cert. denied, 414 U.S. 1135 (1974). The newspapers and speaker programs were run by student groups sanctioned by the university. Both courts said, however, that in spite of their university affiliation and funding, in disseminating viewpoints the student groups were separate, private associations, and did not represent the university. $380 \mathrm{~F}$. Supp. at $1364 ; 353 \mathrm{~F}$. Supp. at 152 . Thus, if the universities reinoved the programs froin student control, it would be tantamount to government censorship. 380 F. Supp. at 1364; 353 F. Supp. at 152. Several courts had held previously that university control over student-run newspapers violated the first amendment. See, e.g., Joyner v. Whiting, 477 F.2d 456 (4th Cir. 1973); Brooks v. Auburn Univ., 412 F.2d 1141 (5th Cir. 1969); Trujillo v. Love, 322 F. Supp. 1266 (D. Colo. 1971); Antonelli v. Hammond, 308 F. Supp. 1329 (D. Mass. 1970). Faced with a conflict between first amendment rights of the student associations and those of the plaintiffs, the courts further reasoned that the newspapers and speaker programs served educational purposes, and free speech and diversity of viewpoint were the essense of university activity. 380 F. Supp. at 1363; 353 F. Supp. at 153. Accordingly, the courts rejected plaintiff' nonassociation claims. (The court in Arrington in fact denied the existence of a constitutional monetary nonassociation claim. It rehed on the reasoning of Justice Harlan in Lathrop v. Donahue, 367 U.S. 820, 851-61 (Harlan, J., concurring). 380 F. Supp. at 1360-62.) 
The interests assertedly protected by compelled contributions to labor unions merit close consideration. A strong union is, $m$ theory at least, in a better position to serve the interests of its members. A strong union may also benefit management, by simplifying employee control and discipline, and by providing a single representative for contract negotiations. ${ }^{140}$ These interests would be threatened, it is argued, if einployees who benefited froin the union's activities were to receive a "free ride."141

The inost extreme expression of the free rider problein is that unions could not exist at all in the absence of compulsory dues. It has been argued that if employees perceive their contribution to the union as insignificant, they will assuine that the union can survive without their contribution. In such a case, if each employee rationally pursues his perceived best interest he will not pay dues. ${ }^{142}$ The evidence, what hittle exists, does not clearly support such a proposition. A study conducted in a state where union security agreements had been banned suggests that union security has hittle impact on union menibership or

140. The purpose of exclusive representation rules, as they now exist, is to allow one party to broker a settlement for the affected workers. See, e.g., Abood v. Detroit Bd. of Educ., 431 U.S. 209, 220-21 (1977); Emporium Capwell v. Western Addition Commumity Org., 420 U.S. 50 (1975). There is a tendency to equate exclusive representation with union security provisions. But exclusive representation is assured regardless of the presence or absence of union security provisions.

141. Because the union possesses total control over the fate of all employees, the Supreme Court decided soon after the first federal labor statutes were enacted that the umion owed a duty of fair representation to all employees. Steele v. Louisville \& Nashville R.R. Co., 323 U.S. 192 (1944). Some argue that this duty justifies union security. See, e.g., Abood v. Detroit Bd. of Educ., 431 U.S. 209, 224 (1977). See generally T. HAGGARD, supra note 18, at 271-78 for a summary of the arguments supporting union security provisions.

142. Economist Mancur Olson, Jr. has written perhaps the most detailed exposition attempting to prove that labor unions provide a collective good which can only be provided if there are compulsory dues. M. Olson, The Logic of Collective Action (1965). Olson's analysis focuses on providing collective goods through collective action, i.e. the private association problem. He compares the individual considering the advantages of joining a private association with the individual firm in a perfectly competitive market. Id. at 1-38. In a competitive market it is clearly in the collective best interest of the competitors to band together and restrict supply. The industry as a whole can then collect a monopolist's profit which can be divided among the individual firms. But because each firm's impact on the market is imperceptible, each firm acts with tunnel vision in pursumg its own interest. Consequently, each firm produces the nost output it can sell and in so doing lowers the overall price of its goods and the total revenue of the group. In making his analogy, Olson states:

The standard for determining whether a group will have the capacity to act, without coercion or induceinents, in its group interest is (as it should be) the same for market and non-1narket groups: it depends on whether the individual actions of any one or more members in a group are noticeable to any other individuals in the group. This is nost obviously, but not exclusively, a function of the number in the group. Id. at 45 .

See also Stigler, Free Riders and Collective Action: An Appendix to Theories of Economic Regulation, 5 BELL J. ECON. \& MGMNT. SCI. 359 (1974). The author theorizes in order to explain the viability of trade associations and other groups that cannot coerce fimancial support. He suggests that there is no such thing as a free ride. The ride is merely cheaper to the noncontributor. The overall benefits provided by the group are reduced by the lack of his support so that the benefits he receives are also lessened. 
effectiveness. ${ }^{143}$ Another study suggests that workers' decisions to join the union are inade independently of rational economic notives, for ideological or psychological reasons. ${ }^{144}$ Indeed, even the proponent of the extreme view admits that the risk of noncontribution is reduced when the union is small, ${ }^{145}$ where the union can offer additional inembership benefits to contributors, ${ }^{146}$ or where membership in the union offers psychic rewards not available to nonmembers. ${ }^{147}$ These exceptions quite likely will apply in a wide variety of union settings. ${ }^{148}$

Second, it is argued that a contract that permits free riders will weaken the union by giving a militant minority faction the power to control union decisionmaking by threatening to withdraw its financial support. In this inanner the state interest in reducing labor unrest will be thwarted. Though there is some empirical evidence to support this argument, ${ }^{149}$ the assuniptions underlying it are far too speculative to justify a judicially recognized first amendment violation. There is no

143. F. MEYERS, "RIGHT-TO-WORK" IN PRACTICE (1959). This ten-year study of the effect of right-to-work laws in Texas on union organizing concluded that the laws had virtually no effect. The author stated that the right-to-work debate is largely a symbolic issue for both sides. Most union officials with whom the author spoke considered the ability of the organizers to be the crucial factor in the success of a union. An analysis of all the locals in the state showed that even though uniou security clauses were banned by state law, only $11 \%$ of the unionized bargaining units had a membership of less than $60 \%$ of the employees. The irony here is that a uniou with only $60 \%$ of the employees in the bargaining unit supporting it is probably too weak to negotiate a union security clause anyhow. It is universally acknowledged that the only unions which can negotiate such clauses are those that are very strong and have been in control of the bargaining unit or otherwise established for a number of years. See also T. HAGGARD, supra note 18, at 285 n.2 (sources cited therein).

144. Seidman, London \& Karsh, Why Workers Join Unions, 274 ANnals AM. ACAD. Pol. \& Soc. SCI. 75 (1951). This study of steelworkers belouging to a large union in Chicago indicates that contrary to Olson's theory, most workers who join unions do so voluntarily because of psychological motivations. The authors of the study found that union members fell into either of two broad categories, (1) those who joined with conviction and (2) those who joined without conviction or in spite of animosity toward unions.

Those who joined with conviction fell into oue of four categories. Some joined because of family background; members of their family were active unionists. Some jomed because prior work or union experieuce had positively reinforced their view of umions. Still others joined because their experience on the particular job site led them to dislike their employer. Finally, a certain portion of the employees joined after they were persuaded by the union organizing campaign.

Those who jomed without conviction or in spite of union animosity did so because of informal peer pressure of varying degrees. The authors found that a significant number of union members joined "the union primarily on the basis of expedieucy, rather than upon any logical analysis of the situatiou."

145. M. Otson, supra note 142 , at $62-63$.

146. Id. at 72-73. Olson gives as examples union pension plans, strike funds and group insurance. He notes the history of the railway workers' unions which flourished for at least two decades without union security agreements. Olson said coercion was unnecessary since the union had seniority rights for members written into their employmeut contracts.

147. Olson admitted the importance of psychological motivations for supporting private associations, but he declined to imclude them in his analysis because they are empirically imestimable. Id. at 53-65.

148. Id. at $132-50$.

149. See T. HAGGARD, supra note 18 , at 284-85. 
reason to assume that umion members would actually withdraw from the umion when they lost a battle in the union hall. There is also no reason to assume that the faction threatening withdrawal will be the most militant regarding labor-management conflicts. The most militant members may be in the majority and the dissenters might be those argning for moderation. Moreover, labor militancy is not necessarily an evil from the government's standpoint, or at least it should not always be so considered. Labor relations statutes are not intended solely to insure labor peace. They are also imtended to insure that einployees have an effective say in the nature of their einployment. If relations between management and the union hierarchy become cozy to the detriment of employees, militancy may be a desirable development. ${ }^{150}$

Finally, it is argued that it is simply unfair to allow free riders to benefit from the union's activities without paying their fair share. As a matter of first amendment law, this moral argument is untenable. Like many private associations, the union confers positive externalities as a result of its creatimg a collective good. ${ }^{151}$ Noncontributors receive "unjust enrichment," but there is no contract law principle that requires one who is involuntarily enriched to trade first amendment rights for that enrichment. The only question of constitutional significance is whether enough employees will contribute to the union to make it financially viable and institutionally stable if employees are not required to pay dues. ${ }^{152}$

Thus, close examination of the necessity for union security agreeinents suggests that such agreenents may not be needed to preserve effective public sector collective bargaining. ${ }^{153}$ Accordingly, these agreements should not be allowed to outweigh an interest in a first amendment right. Dissident individuals should have some relief available, not only to save them money, but also to prevent private groups having greater power from influencing the pohitical process more than their voluntary support warrants.

150. See, e.g., Schatzki, Majority Rule, Exclusive Representation, and the Interests of Individual Workers: Should Exclusivity be Abolished?, 123 U. PA. L. REv. 897 (1975).

151. Cf. FPC v. New England Power Co., 415 U.S. 345, 359 (1974) (Marshall, J., dissenting) (arguing that hicense fees charged to power company by Federal Power Commission are a form of unauthorized taxation because it was very difficult to identify specific beneficiaries of the Commission's services; hence, those services should be considered instead as benefiting broadly the general public); National Cable Television Ass'n, Inc. v. United States, 415 U.S. 336, 340-43 (1974) (fee charged cable television hicensces is a form of unauthorized taxation; this is not a case where "[t]he public agency performing those services . . . may exact a fee for a grant which, presumably, bestows a benefit on the applicant, not shared by other members of society.").

152. See note 143 supra for a demonstration that unions are not at all dependent on compelled contributions for survival.

153. For example, statistics of union growth, particularly in the public sector, show cnormous imcreases in menbership and union power in the absence of union security agreements. See, e.g., International Ass'n of Machinists v. Street, 367 U.S. 740, 754 (1961); A.F.L. v. American Sash Co., 335 U.S. 538, 547 (1949) (Frankfurter, J., concurring); SPERO \& CAPOzZOLA, supra note 124, at 152-53, 161 (see statistics cited); J. STIEBER, supra note 124, at 127-30; Brooks, Stabllity Versus Employee Free Choice, 61 CORNELl L. REv. 344, 347-51 (1976). 


\section{B. Remedy for Violation of Right of Nonassociation}

One of the most difficult issues arising out of nonassociation claims is determining a suitable remedy, particularly when a plamtiff objects to only some of the activities for which support is compelled, as in the union context. Only a brief outline of the applicable law is possible here.

Since the violation to be rectified is government interference with the political process, the remedy must terminate the use of coerced funds for prohibited activities to the fullest extent possible. The goal should be that any organization's pohtical activities are supported exclusively by voluntary contributions. Two significant questions are apparent: How can a court assure a fair and accurate financial segregation of permitted and prohibited activities when an organization carries on both? When will contributions be deemed voluntary, i.e., is an actual waiver required or can it be implied?

The case law on remedies applicable in monetary nonassociation claims has evolved to reach a sensible result. In International Association of Machinists $v$. Street, ${ }^{154}$ the Court decided that because the union's activities were severable from its collective bargaining activities, dissenting union meinbers were obhgated to continue paying soine dues. ${ }^{155}$ The Court further determined that an imjunction against all of the union's expenditures for political activities might violate the first amendment rights of the majority. ${ }^{156}$ Therefore, it concluded that it was a proper remedy to enjom the expenditure of that proportion of the dissenter's dues that the challenged expenditures bear to the union's entire budget. ${ }^{157}$ Justice Whittaker in dissent pointed out that, simce the objector continued to pay the same dues, he would in effect pay a greater proportion of the union's collective bargaining expenses and therefore indirectly subsidize political activities by freeing the dues of other members for that purpose. ${ }^{158}$ The Abood Court agreed with Justice Whittaker's criticism. ${ }^{159}$ The Court said that a remedy was (1) the refund of a portion of the exacted funds in the proportion that union political expenditures bear to total expenditures, and (2) the reduction of future exactions by the same proportion. ${ }^{160}$ Although this remedy does help prevent the use of coerced funds for political purposes, it may prove inadequate. ${ }^{161}$

154. 367 U.S. 740 (1960).

155. Id. at 771 .

156. Id. at 772 .

157. Id. at 775 .

158. Id. at 780 (Whittaker, J., concurring).

159. 431 U.S. 209, 237 n.5 (1977).

160. Id. at 240.

161. Justice Steveus said that a final decision on the proper remedy would have to await development of facts at trial. Id. at 244 (Stevens, J., concurring). On the one hand, the Court has been concerned that an easily obtainable remedy would precipitate a run on the union's treasury. It has also probably been reluctant to impose burdensome accounting costs on the union, making the remedy more costly than the malady. In this situation, however, where the remedy is 
The most glaring problem raised by this remedy is that it provides an incentive for the union to understate the amounts spent on such activities. The Abood Court did not consider how the union could be audited to assure accuracy in calculating the proportions involved. One solution would be to allow dissenters to withhold all of their dues after indicating their ideological objections. This puts the burden of accounting for the relevant expenditures on the union, the party with access to the infornation, and will maximize the objectors' opportumity for checking the union's figures. This conforins with the holding of Brotherhood of Railway Clerks v. Allen ${ }^{162}$ that plaintiffs need only make broad allegations of union pohtical activities and state their objections; they need not object to particular political causes. ${ }^{163}$ This also puts the burden on the union to show which activities are genuinely related to collective bargaining. ${ }^{164}$

The second issue is whether the petition and refund remedy in Abood truly eradicates compulsion. As a rule, an individual can waive constitutional rights only through a knowing and deliberate action. ${ }^{165}$ Abood and Allen make it clear that it is up to the dissenter to make his objections known to the union. Therefore, barring objection, assent is presunied. In the context, this is appropriate as long as individuals are adequately notified of their option of nonsupport, simce the constitutional right is one of witldrawal. A union can provide sufficient notice by apprising members of its present activities and of their power to withdraw. A detailed list of its future activities should be no more necessary than particularized complaimts from dissenters, and any such requirement would undesirably impose on the union's flexibility. After fair notice has been given, a union should be able to collect dues automatically. ${ }^{166}$

\section{IV}

\section{BROADENING THE RIGHT OF NONASSOCIATION}

This Coininent has argued for giving a broad scope to the first amendment right to resist compelled participation in private political organizations. The discussion has concentrated on coerced payments to unions, particularly public employee unions, because most ideological nonassociation cases arose in that area. But outside large metropol-

severance, applications for refunds could ouly pertain to political activities. The Court has decided that these activities are not an essential part of the union's function; therefore, this concern seems inappropriate. The problem is real, however, where, as is suggested in this Comment with regard to public sector unions, dissenters can withhold all dues. Members may withhold dues or file for refunds whenever they want some extra noney regardless of their true behiefs. To the extent that this is destined to occur, however, it is a factor to be considered in assessing the government's interest im coercing financial support.

162. 373 U.S. 113 (1963).

163. Id. at 118-19.

164. Id. at 122 .

165. See, eg., Johnson v. Zerbst, 304 U.S. 458, 465 (1938).

166. See note 88 supra. 
itan areas, public employee unions are of relatively slight political importance. The right of nonassociation has much greater scope, and a greater threat to the right will be posed, if the government has the power to fund private political activity by the use of its power to tax and spend. ${ }^{167}$ The campaign fmancing provisions of Subtitle $\mathrm{H}$ of the

167. Cf. Lathrop v. Donohue, 367 U.S. 820, 852 (1961) (Harlan \& Frankfurter, J.J., concurring) (arguing that first amendment claims by individuals forced to contribute directly to private associations are analytically identical to taxpayer challenges to government programs).

An additional question arises as to what constitutes government action where government expenditures aid political advocacy by private associations. At one extreme lies direct government funding of private associations, as in the funding of election campaigns. At the other extreme are situations where the government tolerates or otherwise indirectly sanctions the ideological activities of private associations. Conceivably, considering the breadth of the right as discussed thus far in this Comment, the government could be implicated in a violation of the right of nonassociation whenever it financially subsidizes a private group in any way. Necessarily, the right must be limited by a standard concept of government action, for example, the "significant government involveinent" test from Moose Lodge No. 107 v. Irvis, 407 U.S. 163, 173 (1972).

Since the coercion of money inust be tied to objectionable ideological activity, express recognition and approval by the government of the activity in question (taking direct funding of the activity as specific approval) would be a suitable requirement. This standard was applied in Public Utilities Comm'n v. Pollak, $343^{\circ}$ U.S. 451, 462 (1952), where the Court found government action because the federally authorized Public Utilities Commission had regulatory supervision over the transit company and had specifically approved the radio broadcasts that were challenged on constitutional grounds. The Commission had the power to halt the radio broadcasts. It ordered an investigation, held public hearings, and approved the practice.

Requiring specific government approval would eliminate taxpayer nonassociation claims where governmeut involveinent with a private association consists of liceusing, (see, e.g., Moose Lodge No. 107 v. Irvis, 407 U.S. 163 (1972)), chartering, (see, e.g., Trustees of Dartmouth College v. Woodward, 17 U.S. (4 Wheat) 518, 635-39 (1819)), or cven general regulatory supervision. In this way, nouassociation claims do not arise simply because the government allows a private association to exist. Nor do they arise whenever the government exercises its police power to inediate the interests of the association and those outside of it.

It is possible that tax exeinptions granted to private associations are sufficient to constitute government action. In McGlotten v. Connally, 338 F. Supp. 448 (D.D.C. 1972) the court held that granting an income tax exemption under I.R.C. $\$ 501(c)(8)$ to segregated fraternal organizations was sufficient government action to support a fifth amendment claim, 338 F. Supp. at 459.

For cases agreeing with McGlotten, see, e.g., Jackson v. Statler Foundation, 496 F.2d 623 (2d Cir. 1974) (if substantially dependent on tax exemption); $c f$. Green v. Connally, 330 F. Supp. 1150 (D.D.C. 1971), affd mem. sub nom. Coit v. Green, 404 U.S. 997 (1971) (no constitutional claim, but finding of state action and denial of tax exemption to private school that discriminates racially). Contra McGlotten, Browns v. Mitchell, 409 F.2d 593 (10th Cir. 1969) (dismissal of students by private university for sit-in demonstration); Stearns v. Veterans of Foreign Wars, 394 F. Supp. 138 (D.D.C. 1975) (no state action where tax exeinpt group excludes women meinbers, distinguishing $M c$ Glotten on grounds that racial discrimination is scrutinized more strictly).

The Court in Walz v. Tax Comm'n, 397 U.S. 664 (1970), held that the exemption of church property froin state property tax did not violate the establishinent clause. The McGlotten Court distinguished Walz, saying the opimion was based on historical exemptions for churches, and a policy of "benevolent neutrality toward churches," 388 F. Supp. at 459 n.58 quoting 397 U.S. at 676. See also Greenya v. George Washington Univ., 512 F.2d 556, 560-61 (D.C. Cir. 1975), where the court cited Walz for the proposition that a tax exemption is not enough to constitute government action.

As a practical matter the McGlotten holding might not have wide application in the monetary nonassociation area as I.R.C. $\$ 501(c)(3)$ denies the exenption to organizations with substantial activities carrying on propaganda, political campaigns on behalf of any candidate for public office, or otherwise attempting to influence legislation. I.R.C. $\S 501(\mathrm{~h})$, however, permits certain 
Internal Revenue Code, which provides for public financing of presidential elections, is a powerful exainple of this kind of activity. ${ }^{168}$

The provisions of Subtitle $\mathrm{H}$ allow taxpaycrs wishing to contribute to the federal campaign fund to earmark one dollar of existing tax liability for that purpose. ${ }^{169}$ Funds collected by this method are disbursed to contending political parties. Fund disbursements are based on past electoral performance. In consequence, the Democratic and Republican parties receive a substantial subvention. ${ }^{170}$ Indced, Subtitle $\mathrm{H}$ may assure them an unwarranted political permanence. Parties which received less than five percent of the vote in the previous national election receive no government funds and must therefore selffinance. ${ }^{171}$

In Buckley v. Valeo ${ }^{172}$ the Supreme Court held that this scheine did not violate any first ainendinent interest. ${ }^{173}$ The Court rejected the plamtiffs' argument that the program constituted compelled support of political activity. Rather the tax return checkoff was simply a means

groups to spend a limited amount on lobbying for the purpose of influencing legislation. Thus, soine claims may still exist.

168. Presidential Election Campaign Fund Act, Pub. L. 92-178, § 801, 85 Stat. 562 (1971), I.R.C. $\$ \S 9001-13$; Presidential Primary Matching Payment Account Act, as amended by Pub. L. 93-443, $\S$ 403-408, 88 Stat. 1291 (1974), as amended by Pub. L. 94-283, §§ 301-07, 90 Stat. 497 (1976) I.R.C. $\$ \S 9031-42$.

169. I.R.C. \& 6096.

170. "Major parties," defined as those receiving $25 \%$ or more of the vote in the last preceding election, I.R.C. $\S 9002(6)$, receive $\$ 2,000,000$ for nominating convention expenses, 1.R.C. $\S$ 9008 (c)(1), and $\$ 20,000,000$ for the general election campaign. I.R.C. $\$ 9004(\mathrm{a})(1)$.

"Minority parties," defined as those receiving from $5 \%$ to $25 \%$ of the vote in the last precedimg election, I.R.C. $\$ 9002(7)$, receive advance funding based on the ratio of the votes received by the party's candidate to the average of the votes received by the major parties' candidates, I.R.C. $\S \S$ $9004(\mathrm{a})(2)(\mathrm{A}), 9008(\mathrm{~b})(2)$, and can receive post-election funding in addition if they increase their vote share. I.R.C. $\$ 9004(\mathrm{a})(3)$.

"New parties" are all other political groups. I.R.C. $\$ 9002(8)$. They receive no advance funding at all. If they receive $5 \%$ of the national vote they qualify for post-election funding. I.R.C. $\$ 9004(\mathrm{a})(3)$. No fmancing is provided for independent candidates. Convention funds are not provided for parties not holding a convention. Buckley v. Valeo, 424 U.S. 1, 88-89 (1976).

I.R.C. $\$ \$ 9003(\mathrm{~b})$ and $9004(\mathrm{a})(\mathrm{l})$ prevent Presidential candidates who receive pubhic funding equivalent to their full entitlement from accepting private contributions. Public funding for inajor parties, however, was originally equal to the inaximum amount that can be spent on a campaign, \$20,000,000. 18 U.S.C. $\$ 608$ (c)(1)(B) (Supp. IV (1974)) (repealed 1976). With funding based on preceding elections one would expect the Deinocrats and Republicans to receive most funding for the foresceable future. If inoney can be said to be a crucial factor in political success the two major parties should continue to thrive. See text accompanying note 110 supra.

171. I.R.C. $\$ 9004$.

172. 424 U.S. 1 (1976). See generally Note, 90 HARV. L. REV. 179 (1976).

173. 424 U.S. at 85-109. In addition, the Court uplield limitations on individual contributions to a particular candidate of $\$ 1000, i d$. at 29 , of total contributions per individual per year of $\$ 25,000$, id. at 38 ; and a $\$ 5,000$ limitation on contributions by a political committee to a single candidate. Id. at 35. The Court rejected limitations of $\$ 1000$ on individual expenditures "relative to a clearly identified candidate," $i d$. at 51 , and any limitations on expenditures by candidates from personal or family resources, id. at 54 , and limitations on overall expenditures by a candidate. Id. at 55-7. Distinctions drawn by the Court lave been criticized. See, e.g., Note, 90 HARV. L. REV. 179 (1976). 
of structuring an appropriation from general revenues. ${ }^{174}$ The Court also dismissed the argument that the first amendment, "by analogy" to the establishment clause, created an interest for plaintiffs attempting to halt the use of government funds and expertise, paid for in part with their tax dollars, to support the two dominant political parties. ${ }^{175}$ The establishment clause, the Court replied, was limited solely to religious activity. ${ }^{176}$

The only claim the Court recognized was that of minority parties assertimg that the Congressional program deprived them of equal protection of the law. ${ }^{177}$ Once the court determined that the equal protection claim did not require "exactimg scrutiny," thus allowing it to defer, overturning the challenge was a relatively easy process. ${ }^{178}$ The Court

174. 424 U.S. at $91 \&$ n.124. The Court's argument that the tax checkoff is not coercive because the program is funded from general appropriations parallels an argument that unions do not collect dues for political activities from dissenters, but they collect an equal sum from all employees, and some expenditures happen to go for political activities. The latter argument has been rejected by the Court. Abood v. Detroit Bd. of Educ., 431 U.S. 209, 237 n.35 (1977); Retail Clerks Int'l Ass'n v. Schermerhorn, 373 U.S. 746, 753-54 (1963). See text accompanying notes 154-61 supra.

175. 424 U.S. at $92-93$ n.127. The Court's brief analysis was criticized by Chief Justice Burger. He perceived great risks in public financing of election campaigns, calling it a form of "incest." Id. at 248-50 (Burger, C.J., concurring and dissenting).

176. Id. at 93.

177. Id. at $93-97$.

178. Id. at 94 . The conclusion that the Court did not apply a strict scrutiny test follows by implication. First, the Court distinguished the devial of public funding to minority parties from cases finding equal protection violations under state restrictions on access to the electoral ballot, citing American Party of Texas v. White, 415 U.S. 767, 780-81 (1974), Lubin v. Parish, 415 U.S. 709, 716 (1974) and Storer v. Brown, 415 U.S. 724, 729-30 (1974). Accordingly, the Court said the government did not have to show there were no less drastic alternatives, as it was required to do in the ballot-access cases. 424 U.S. at 101. The Court called ballot restrictions "direct burdens not only on the candidate's ability to run for office, but also on the voter's ability to voice preferences regarding representative government and contemporary issues." Id. Public fmancing was not restrictive of these rights, the Court said. It said any ineffectiveness of minority parties results from their inability to raise fmancial support, not from public financing. Id. at $94 \mathrm{n} .128$. Yet the Court cited the Campaign Act's limits on private funding as an important reason for providing public financing, id. at 96 , though earlier in its opimion it stated that contribution limitations would not severely hamper unfunded parties. The inconsistency results from an overly deferential attitude to the Congressional scheme.

The Court further reasoned that prior electoral returns were the most objective ineasure of support, id. at 100-02, and that it wonld be undesirable to give candidates public noney where the support was lacking and senseless to "fund hopeless candidacies with large sums of public money," id. at 96, though it did not specify why and at what level of funding waste would occur. Moreover, the major governmental imterest asserted was in reducing the influence of wealthy contributors. Id. at 96 . But the same purpose justified extensive limitations on contributions by individuals and organizations. The Court did not indicate how public financing was necessary, in addition to those limitations. It determined that the public financing provisions were "severable" from invalidated sections of the Federal Election Campaign Act, 18 U.S.C. $\S 608$ (a),(c),(e)(1) (1970 Supp. IV). If the Court was strictly scrutinizing Snbtitle $\mathrm{H}$, one would expect its discussion to emphasize how the ineasure advances the major government interest asserted. Id: at 108-09. Instead, it dismissed arguments that the scheme was detrimental to minority parties, and the politi cal system, in general, as wholly speculative. Id at 96, 101. "Any risk of harm to minority interests is speculative due to our present lack of knowledge of the practical effects of public financing . ..."Id. at 101. It follows that the Court deferred completely to Congress. 
simply noted that minority parties were not absolutely deprived of funds; they could always obtain reimbursement after the election if they secured enough votes. ${ }^{179}$ The Court flatly stated that if minority parties cannot raise enough money or inspire a sufficient number of voters then they should not receive federal money. ${ }^{180}$ The statute's system of allocating funds was deemed to be a rational approach that legitimately inet Congress's goal of curbing campaign corruption.

The ease with which the Court overruled the plaintiffs' equal protection challenge and sustained the campaign financing provisions illustrates the importance of a principle of nonassociation. By limiting its focus to the equal protection claim the Court was able to direct attention to the way in which the cainpaign funds are distributed. The allocation formulas devised by Congress may well be the fairest and most practical inethod of carrying out the program. Such an analysis, however, begs the issue. The Court's holdings in Elrod and Abood both suggest that the current structure of the fmancing program does infringe a first amendment interest. The impact of the program is clearly to favor the larger and better established political organizations - the precise constitutional injury that was recognized in Elrod and, by implication, in Abood. Indeed, when the government acts as fundraiser the problem is exacerbated; since the government's capacity for fundraising is so enormous a small collection froin each individual can establish a very large and powerful organization. Moreover, the individual injury to the taxpayer, although slight, is nonetheless tangible. As a result of the government's free choice problem, certain voters are allowed to designate a percentage of their total tax liability to support the nation's two dominant ideological organizations. In consequence, the proportional tax liability of noncontributing dissenters is increased, albeit fractionally, to cover the diversion of revenue to the public financing prograin. Further, government mechanisms, inevitably financed by tax revenues, are employed toward the advancement of political parties the taxpayer inay oppose, not only because the two major parties so overwhelm any potential competitors, but also because the government supports any of several political parties, none of which may ineet with the taxpayer's ideological approval. Although the imjury to the individual is slight in monetary terms, there is no reason for viewing it as constitutionally insufficient. ${ }^{181}$

A recognition of this first amendment interest would have forced the Buckley Court to truly test the nature of the government's countervailing interest. Surely, if public fmancing of elections were essential

179. Id. at $94-95$.

180. Id.

181. In describing why contribution limitations were not a significant infringement of first amendment rights, the Court in Buckley suggested that amounts were immaterial; whether the individual gave $\$ 1,000$ or more, the strength of his conviction was roughly the same. 424 U.S. at 21. Cf. Flast v. Cohen, 392 U.S. 83 (1968) (statns as federal taxpayer sufficient to give claimant requisite personal stake in outcome of hitigation not because of the financial value of the claim but becanse of the type of claim asserted). 
to preservation of meaningful electoral participation, public fimancing could be justified. ${ }^{182}$ The Federal Elections Campaign Act contained other provisions restrictimg campaign contributions and expenditures ${ }^{183}$ provided for disclosure of virtually all contributors. ${ }^{184}$ The Court upheld some of these provisions and struck down others by varying its assessment of the government interest and of the first amendment injuries in each case. ${ }^{85}$

The government's interest for all the provisions was the prevention of electoral corruption. A close scrutiny of the correlation of this interest with the necessity for providing support to Presidential campaigns should liave lead the Court to find a first amendinent violation. ${ }^{186}$

182. See text accompanying notes $135-39$ supra.

183. See note 172 supra.

184. 2 U.S.C. $\$ 431$ (1970 Supp. IV).

185. See The Supreme Court, 1975 Term, 90 HARv. L. Rev. 56, 179 (1976).

The Supreme Court previously has justified the infringement of first amendment rights in order to expand or give effect to the first amendment rights of the majority. See Burns v. Elrod, 422 U.S. 347, $370-71$ (1976) and 427 U.S. at $386 \mathrm{n.9}$ (Powell, J. dissenting). Another example is government regulation of radio and television broadcasting. See Red Lion Broadcasting Co.v. FCC, 395 U.S. 367 (1969) (Regulation is essential to provide order in the distribution of wave frequencies, thus insuring that coherent presentations can be made to the public without interference from competing broadcasts). See also Columbia Broadcasting System, Inc. v. Democratic National Committee, 412 U.S. 94 (1973); Canby, The First Amendment and the State as Editor: Implications for Public Broadcasting, 52 TeXAs L. Rev. 1123 (1974).

186. Cf. First National Bank of Boston v. Bellotti, 98 S. Ct. 1407 (1978). A Massachusetts statute restricted the ability of banks and business corporations to participate in voter referenda. The Massachusetts high court held that a business corporation had no first amendment rights in this area outside of matters materially affecting its busmess. It then upheld the statute on equal protection grounds. The U.S. Supreme Court disagreed on the first amendment point. It rejected the analysis of the state's interest conducted by the Massachusetts court which did not apply a strict scrutiny test. The Court applied strict scrutiny to to the two interests asserted by the state: sustaining the active role of the individual citizen in the electoral process, thereby preventing a diminution of citizens' confidence in government; and protecting rights of shareholders whose views differ from those expressed by management on behalf of the corporation. Id. at 1422 .

The Court rejected the first contention saying that the argument that the wealthy and powerful will drown out other viewpoints lacked support. Id. at 1423. It distinguished federal campaign restrictions upheld in Buckley from the referendum restrictions here, arguing that the presence of candidates in the former situation created a real danger of corruption. Id. at 1422 n.26.

The Court assumed arguendo that the second state interest was compelling but rejected the statute as bearing an insignificant relationship to the state's goal since many institutions and political activities, such as lobbying, were not covered by the statute. Id. at 1424-26. Iromically, the Abood opinion denies dissenters the right to object to many public union political activities. See text accompanying notes 54-67, 124-34 supra. 1434.

The dissent accused the Court of substituting its judgment for that of the state. Id. at 1430,

In Buckley, the Court had before it every conceivable challenger to the public fimancing provisions, other than an independent candidate unaffiliated with any party. 424 U.S. 1, 7-8, 87 n.118. All the claims were unsuccessful. From the Court's opinion, it appears that the best result they could have gotten was to reccive more money as minority candidates, and this only through the equal protection claim rejected by the Court. See note 177 supra. That claim is not relevant where the objection is to the concept of public funding of elections. See 424 U.S. at 246-50 (Burger, C.J., dissenting); 120 Cong. Rec. § 202 (1974) (Remarks of Sen. Baker). Public funding 
There was no showing that private contributions per se cause corruption. Further, providing financing for Presidential elections while leaving Congressional caunpaigns completely dependent on private support only marginally reduces corruption, and more likely it simply relocates it. This incremental decrease in the harm being remedied fails to justify the infrimgement of first amendment rights of taxpayers, and suggests that Congressional action may have been disingenuous. ${ }^{187}$ Even if these arguments are not completely convincing as policy, the Court should have invalidated the program because the government failed to carry its burden of proof to justify the infrimgement. By blinding itself to the first amendment interests at stake, the Court upheld the program as having a rational basis but only at the price of allowing a government prograin of dubious constitutionality to remain virtually unexamined.

The major obstacle to a successful challenge of the government financing provisions of Subtitle $\mathrm{H}$ is the restrictive rule of Frothingham v. Mellon, ${ }^{188}$ which has denied taxpayer standing to raise constitutional claims in the federal courts and allowed the Buckley Court to avoid consideration of taxpayer interests. The rule of Frothingham has been nodified to allow for taxpayer standing in suits under the establishinent clause, ${ }^{189}$ but the Court has avoided further contractions of the rule. ${ }^{190}$ The case of federal campaign financing presents an appropriate instance in which to allow taxpayer standing. The imjury to be avoided is a substantial one. Means of redress through the political process

does not serve to restrict the functioning of minority parties, see note 177 supra, as contribution and expenditure limitations might; rather, it enhances their competitors. If only the harm to other pohtical parties is examined, the equal protection claim is mevitably all that can be raised. When the harm is recognized as bemg to socictal interests, however, the scheme of public funding must be seen as a first amendment violation.

187. In Bellotti, the Court found it ironic that the state would assert a need to prevent corruption when the statute was directed only at corporate participation in referenda, and made no nention of corporate lobbying. "Presumably the legislature thought its inembers conpetent to resist the pressures and blandishments of lobbying, but had markedly less confidence in the clectorate." $98 \mathrm{~S}$. Ct. at 1424 n.31. See also note 186 supra.

188. 262 U.S. 447 (1923).

189. Flast v. Cohen, 392 U.S. 83 (1968).

190. Compare Schlesimger v. Reservists Comm., 418 U.S. 208 (1974); United States v. Richardson, 418 U.S. 166, 179 (1974) and id. at 196, 203 (Powell, J., concurring) with Tilton v. Richardson, 403 U.S. 672 (1971) and Flast v. Cohen, 392 U.S. 83 (1968). See Scott, Standing in the Supreme Court-A Functional Analysis, 86 HARv. L. Rev. 645, 662, 687 (1973). See also United States v. American Friends Service Committee, 419 U.S. 7 (1974); but see, McGlotten v. Connally, 338 F. Supp. 448 (D.D.C. 1972) (Black American has standing to challenge federal support of segregated fraternal organizations by grants of tax exemptions). And to show that even thc establishment clause cannot be used by a taxpayer when it involved petitioning a court to stop a war, see Autenreith v. United States, 279 F. Supp. 156, affd sub nom. Autenreith v. Cullen, 418 F.2d 586 (9th Cir. 1969), cert. denied, 397 U.S. 1036 (1970).

Of course, states may grant taxpayers standing to sue and federal courts might still hear the case. See, e.g., Adler v. Board of Educ., 342 U.S. 485, 497 (1952) (Frankfurter, J. dissenting); Doremus v. Board of Educ., 342 U.S. 429 (1952); Booth v. Gencral Dynamics Corp., 264 F. Supp. 465 (N.D. Ill. 1967). For an example of a state statute expressly permitting taxpayer suits against state and local governments see CAL. Civ. Proc. Code $\$$ 526(a) (West 1972). 
may be difficult or impossible to obtain. Often it is the legislators themselves, or at least a majority of them, who stand to gain the most froin such programs. ${ }^{191}$ Moreover, recognition of standing here would not lead to a flood of litigation challenging such enactments, which are relatively rare. Nor would it necessarily lead to wholesale invalidation of such government programs. Instead, it would permit detailed and skeptical judicial scrutiny im order to assure that sucli intrusions into the political process are fully justified by compelling state concerns.

The final issue is the appropriate remedy in a successful claim against Subtitle $\mathrm{H}$. The remedy suitable in the context of unions is wholly inappropriate here simce the petition and refund process is so burdensome. And the danger of the program is far more inclusive than mjury to particular individuals; it is the overall effect of the prograin that inust be rectified. The only feasible remedy to achieve this purpose is to invalidate the entire program. ${ }^{192}$

\section{CONCLUSION}

Monetary nonassociation rights can serve an important function of checking government intrusions upon the free selection of ideologies. The right fills a void in the enforcement of first amendinent interests. It is the only right encompassing the interests of people, like einployees forced to support the ideological activities of unions, who are coerced to render direct financial support to private associations. It seems to be the only effective way to check the actions of the majority im legislative bodies that are intcnded to support sympathetic private groups of an ideological nature. After Buckley v. Valeo equal protection challenges by competing groups in such situations appear to be of little utility. The monetary nonassociation rights should serve as a proper limit on this type of government entanglement with the private sector.

Like most constitutional rights, this one is subject to abuse. The concerns in this regard are acute with a right tied to 1noney, as this one is, since expenditures of money permeate every aspect of government activity. If properly limited to circumstances involving government support of the ideological activities of private groups, however, the right should prove practicable. Certainly, courts will experience difficulty in determining just which private groups and activities are ideological sucli that government support of thein offends the Constitution. Courts have encountercd and disposed of similar problems in the past, however, even though their analyses may not have been logically pure. Similar resolutions can be effected in this area as well. The Court in Abood defined the constitutional right and suggested a blueprint for analysis. Though the Court's treatment of the issues was not particularly satisfying, it was a beginning in a new area of constitutional law. Judicial resolve to halt a governmental trend of supporting private in-

191. See Buckley v. Valeo, 424 U.S. 1, 251 (Burger, C.J. dissenting).

192. See, eg., Committee for Public Educ. v. Nyquist, 413 U.S. 756 (1973); Lemon v, Kurtzman, 403 U.S. 602 (1971); Doremus v. Board of Educ., 342 U.S. 429 (1952). 
terest groups should result in workable standards once cases come before the courts. This Comment has, I hope, presented one set of useful guidelines.

Alan B. Kalin*

- B.S. 1974, University of Illinois, J.D. 1978, Boalt Hall School of Law, University of California, Berkeley. 